\title{
EARLY OLD ENGLISH FOOT STRUCTURE
}

\author{
By Nelson Goering \\ University of Oxford
}

(Received 10 November, 2015)

\begin{abstract}
The variable operation of high vowel deletion in Old English has long been a point of difficulty, both descriptively - a prehistoric form like *heafudu is attested variably as héafudu, hēafdu, and hēefod - and theoretically. Recent work, especially by BermúdezOtero (2005b) and Fulk (2010), has indicated that plural forms like héafudu are most likely original, but accounting for why the medial $* u$ is preserved in this case form, and not in heafde, the dative singular of the same word, has remained theoretically problematic. These difficulties arise from attempting to describe the prehistoric Old English process of high vowel deletion on the basis of later Old English phonology. At an earlier stage, the nominative-accusative plural *héafudu could be exhaustively parsed into two precisely bimoraic feet: *[hēa][.fu.du]. The dative singular historically ended with a long vowel, *he्efude, in which the medial *u could not be accommodated within

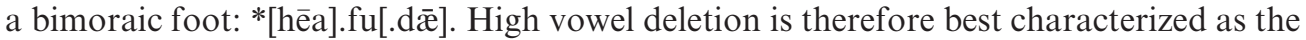
deletion of unfooted high vowels in early Old English, initially operating while length in unstressed vowels remained contrastive. Both this quantitative system and the preference for precisely bimoraic units receive support from Kaluza's law, an archaic metrical phenomenon in Beowulf which prohibits resolution in secondary metrical ictus if the resulting unit would have more than two moras, and which is sensitive to prehistoric length distinctions. This original system was obscured, linguistically and metrically, in later Old English by the shortening of unstressed long vowels, triggering various morphological reanalyses of the effects of high vowel deletion. A review of these changes suggests that the system of metrical phonology described here provides a more plausible starting point for the reworkings that produced the forms found in later Old English than do alternative accounts such as those of Campbell (1983) or Ringe (2002).
\end{abstract}

\section{INTRODUCTION}

The rhythmic or prosodic structures of the early Germanic languages have been a topic of considerable interest to philologists and linguists over the years, and for good reason: the various issues of vowel loss, 'resolution', and the relationship of phonology to poetic metre are bound up with relatively involved issues of description and theory. ${ }^{1}$ The foot structure of Old English has received particular attention during the past several decades, partly as a result

\footnotetext{
1 A draft of this paper was presented at the 20th Germanic Linguistics Annual Conference (GLAC-20) in Purdue on 2 May 2014. My thanks go to Robert W. Murray, R.D. Fulk, and Shaun Hughes for their helpful comments on that occasion. I would also like to thank Don Ringe for kindly providing me with an off-print of his 2002 paper. I am especially grateful to Ricardo Bermúdez-Otero and an anonymous referee for their many helpful comments, corrections, and suggestions.
} 
of the language's general popularity among theoretical phonologists and partly due to the comparatively rich evidence for phonological processes it provides.

Despite a long research tradition, much remains unclear about Old English foot structure. There are at least two reasons for this. One is uncertainty about the scope of syncope and apocope of high vowels, whose loss or retention supplies much of the best evidence for the detailed workings of Old English prosody. It is not always clear which lost vowels have been deleted phonologically, and which have been restored or eliminated on a morphological basis. Much traditional research has assumed that a pre-OE form like *héafudu 'heads' regularly became heafdu, with syncope of the medial vowel, which has influenced the theoretical description of Old English metrical phonology. In recent years, a general unease with this assumption (see e.g. Hogg 2000) has resulted in several well-developed challenges and alternative proposals regarding the operation of high vowel deletion. Ringe (2002) has argued for a far more sweeping loss of high vowels, with a consequently greater role for morphology in restoring lost vowels. The opposite approach is taken by Bermúdez-Otero (2005b), and Fulk (2010), who have both made compelling arguments that there was no vowel loss at all in heafudu, with both unstressed vowels retained phonologically. This last view has the most to recommend it as representing the oldest pattern, both textually and in terms of the morphological assumptions required to account for variants.

Beyond recovering the original pattern of high vowel loss, describing the proper conditioning of the process in phonological terms has proved challenging. Particularly important is the contrast between NOM.-ACC.PL heafudu and the syncopated DAT.SG of the same word, hêafde, which has proven difficult to account for in terms of later Old English phonology. I argue that both the patterns of vowel loss and the phonological conditioning can be described in simple terms for an early stage of Old English, while there was still a distinction between long and short unstressed vowels: syllables were grouped into precisely bimoraic feet, and unfooted high vowels were deleted. In the different case-forms of *héafud, the weight of the final syllable determined whether or not the medial syllable could be footed and preserved, or unfooted and deleted. This view of Old English foot structure receives support from the metrical rule known as Kaluza's law, which depends on precisely the same preference for precise bimoraicity, and whose regular operation was similarly disrupted by the shortening of long unstressed vowels in the 8th and early 9th centuries. I use the term EARLY Old ENGLISH as a general term for the language before this shortening occurred, encompassing both late prehistoric Old English and, at least potentially, the most conservative preserved texts (especially Beowulf).

The first sections of this paper will review the background of the problems regarding resolution and high vowel loss in Old English, before moving on to discussion of Old English foot structure. This will be followed by an overview of Kaluza's law, and the relationship of this metrical phenomenon with early Old English phonology. The remainder will deal with a number of specific words and morphological categories which have a bearing on reconstructing the workings of Old English prosody, and show the morphological and phonological responses to the obscurity created by the shortening of unstressed long vowels.

\section{The BACKGROUND OF THE PROBLEM}

The importance of foot structure in conditioning the loss of high vowels in Old English can be simply illustrated by the NOM.-ACC.PL endings of neuter $a$-stem nouns (Hogg [1992] 2011: 220). The pre-OE form of this ending was ${ }^{*}-u,{ }^{2}$ and is preserved as such after initial light syllables:

\footnotetext{
2 This was shortened and raised in Northwest Germanic from Proto-Germanic (PGmc) *-o, itself from Proto-IndoEuropean (PIE) * $-e H_{2}$ (Ringe \& Taylor 2014: 15f.).
} 
fat $-u$ 'cups' $<* f a t-u$. After heavy syllables, the ending is apocopated, giving word 'words' $<$ *word $-u$. That the relevant process operates at a domain larger than the syllable is shown by the same apocope occurring after disyllabic werod 'troops' $<*$ werud-u, even though the immediately preceding syllable is light.

This process of final high vowel apocope potentially affected a large number of morphemes in pre-OE. Final $*_{-} u$ also marked the NOM.-ACC.SG of $u$-stems and the NOM.SG of feminine $\bar{o}$-stems. Final $*_{-} i$ was found in $i$-stem case forms, and originally also in the primary verbal endings. In addition, high vowels in open syllables were also often lost word-internally, which could result in paradigmatic syncope of stem vowels. For example, pre-OE NOM.SG *druhtin 'lord, GEN.SG * druhtinces become OE dryhten, dryhtnes. By and large, light-stemmed words do not show such alternations: NOM.SG steaðul 'foundation', NOM.PL steaðelas $<{ }^{*}$ staðul, ${ }^{\text {staðulōs. }}{ }^{3}$

Of particular interest are words and categories in which the pre-OE form had two unstressed high vowels in succession after a heavy syllable, as in NOM.PL *heafudu 'heads'. Such words show a great deal of variation in what vowels are actually found in our texts, and it is not always immediately obvious which developments are straightforwardly phonological, and which have been altered morphologically. The single lexeme héafudu alone is found in

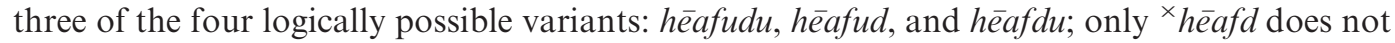
occur (Fulk 2010: 137). A robust theory of high vowel deletion needs to not only describe a coherent original phonological process, but also provide a plausible morphophonological account of the later attested forms.

In addition to the phonology of high vowel loss, poetry provides substantial evidence for higher levels of prosodic organization. The basic argument for resolution in Old English metre was presented by Sievers (1885: 219), and the principle remains fundamental to all mainstream theories of metre (Cable 1991: 141ff; Russom 2002; Yakovlev 2008: 60-4, 756). ${ }^{4}$ As Sievers observed, the necessity of resolution can be seen in looking at what half-line patterns fail to occur, or are found so extremely rarely that they are under strong suspicion of being textual errors. For example, while verses such as waldend sealde (Beo 1693b 'the Ruler gave') are common, perfectly imaginable verses such as ${ }^{\times}$metod sealde, with the same meaning, occur 'so gut wie nie' (Sievers 1885: 219). This strongly implies that disyllables with a short initial syllable resolve to form a single metrical unit, so that ${ }^{\times}$metod sealde fails to meet the minimum number of positions required in a half-line (compare the equally unmetrical ${ }^{\times}$god sealde). ${ }^{5}$

The basic operation of poetic resolution is relatively uninformative concerning foot structure more generally: it concerns stressed syllables only, whereas the most problematic aspects of Old English metrical phonology involve unstressed syllables. Metrical evidence for resolution under lower stress comes from just one phenomenon in verse, Kaluza's law, which is found only in Beowulf. This law, which requires secondarily stressed sequences to be precisely bimoraic (rather than simply minimally so), does not provide enough evidence to

\footnotetext{
3 There was also syncope of non-high medial vowels, but this seems to have been largely weight insensitive, and will be set aside here. Additionally, syncope of high vowels is occasionally found in light-stemmed words, but this most likely only arose analogically, on the model of words that showed syllabicity alternations from parasiting. For these secondary developments in Old Mercian, see Dresher ([1978] 1985: 52); more generally, see Fulk (2010: 130) and Ringe \& Taylor (2014: 273-79)

${ }^{4}$ For a more sceptical view that nonetheless acknowledges resolution at least as a metrical phenomenon, see Stockwell and Minkova (1997).

5 The phrase god sealde occurs within a larger half-line at Beo 72b, 1271b, 1751b, and 2182b, in all cases preceded by unstressed syllables. A major theoretical alternative to a positional analysis of Old English metre is the word-foot theory of Russom (1987; 1998). Within this framework, lines like metod sealde and god sealde are unmetrical not just because they fail to meet normative weight, but also (and more importantly) because they would overlap with wordfeet such as meodosetla and weorðmyndum. It is a basic principle of this approach that a verse-constituent (a wordfoot) must be smaller than a full verse: if a pattern serves a valid word-foot, it cannot also be a valid verse (Russom 1987: 26ff.).
} 
work out a full theory of foot structure. It can, however, offer a degree of corroboration of phonological theories based on the operation of high vowel loss.

\section{Previous phonological theories}

A number of recent theoretical phonological accounts of high vowel loss have assumed that the regular phonological development of a word like *héafudu was to *hēafdu, with syncope but not apocope, following Sievers (1878: 93-5) and later grammarians. ${ }^{6}$ This is most likely not correct (see below, section 4), but the attempts to develop a coherent metrical phonology for $\mathrm{OE}$ have nonetheless resulted in a number of useful observations and theoretical tools.

Much of the relevant theoretical apparatus has been applied to Old English by Keyser \& O'Neil (1985: 4-12), who accurately capture the equivalence of light disyllables with heavy syllables in explicitly theoretical terms through a process of grouping moras. Assuming that short vowels contributed one mora, long ones two, and consonants in a syllable coda a mora each, Keyser and O'Neil $(1985: 6,10)$ are able to give a rule to group these moras 'from left to right into binary, quantity-sensitive, right-headed trees', and delete high vowels immediately following heads. This formulation was picked up by Hogg ([1992] 2011: 222), who rephrased the rule:

[I]f we assume that OE syllables were grouped into 'rhythmemes', and that rhythmemes contained maximally one heavy syllable or two light syllables, and that the head of the rhythmeme is the right-most node, it is possible to state the environment for [high vowel deletion] as being an unstressed high vowel immediately preceded by the head of a rhythmeme.

In a word like /hêafudu/, this process would take the initial syllable as a 'rhythmeme' and accordingly delete the following $-u$ - by rule. This approach has been heavily criticized for the unsupported right-headedness of these groups, and the inapplicability of this 'rhythmeme' structure to any other Old English phonological process (Dresher \& Lahiri 1991: 252), but its binary groupings do provide a starting point for more acceptable descriptions of Old English metrical phonology. However, even as later accounts have reacted strongly against the theoretical formulations of Keyser \& O'Neil, many have retained its descriptive target: to delete high vowels immediately following a heavy unit.

Both parts of this last statement are particularly true of Dresher \& Lahiri (1991), who improve on Keyser \& O'Neil (1985) by attempting to achieve the same descriptive process of vowel deletion through a more consistent theoretical approach. The main innovation is the proposed 'Germanic foot', a metrical structure which is intended to account for a number of prosodic processes not only in Old English, but in the other old Germanic languages as well (especially Sievers's Law as it operates in Gothic).

This 'Germanic foot' is relatively complex, consisting of a strong branch followed by a weak branch (Dresher \& Lahiri 1991: 254-259) The strong branch must contain at least two moras, and can be disyllabic if necessary; the weak branch must be monomoraic, and will be left unfilled if necessary. Basic monosyllables like word 'word' fill the heavy branch on their own, with the weak branch left empty. When a light ending, such as the DAT.SG $a$-stem $-e$ is added, both branches are straightforwardly filled: [wor.d-e] (I use brackets to mark out feet, the hyphen to show the boundary between the strong and weak branches, and . to indicate the beginning of a non-initial syllable). If the ending is heavy, it cannot stand in the light branch

\footnotetext{
${ }^{6}$ For a notable exception, see Kiparsky \& O'Neil (1976: 531), and also the doubts in Hogg (2000). On Sievers's later views, see Fulk (2010: 129f.).
} 
(with its strict monomoraic limit) and instead constitutes the heavy branch of a new foot, e.g. GEN.SG [wor][.des] (with two feet, neither of which has an overt light branch). Since the initial branch must have at least two moras, both syllables of a word like werod are needed to fill the heavy branch, [we.rod]. This is the basis for resolution in verse.

Based on this foot structure, high vowel deletion is framed as a rule operating on high vowels standing in the light, right-hand branch of the Germanic foot (the light branches are underlined for clarity in example (1)):

(1) a. [sci.pu] >scipu

b. [wor-.du] $>$ word

c. [we.ru-.du] $>$ werod

d. [hēa-.fu].du $>$ hêfdu

At least for West Saxon, the actual vowels which are held to be deleted are the same as for Keyser \& O'Neil, ${ }^{7}$ and there is a certain commonality of approach: the position immediately following a heavy, (minimally) bimoraic unit is specially marked out by the phonology. However, Dresher and Lahiri have attempted to describe this position using a foot that also works for stress assignment (and so is trochaic instead of iambic), and which can have more direct relevance for resolution in poetic metre. Nonetheless, this foot is relatively complex and typologically unusual (Hayes 1995: 71). There is also a potential diachronic criticism: the Germanic foot is hardly to be projected back to Proto-Indo-European, but there is no clear motivation for such a specific prosodic pattern to have arisen during the development of preGermanic (this is of course related to the typological markedness of the foot type, since a simple and basic foot type, even when an innovation, requires less diachronic motivation than a complex and exceptional one).

A considerably simpler type of foot, which still attempts to serve most of the same functions as Dresher \& Lahiri's (1991) model, is proposed in Idsardi (1994). Idsardi (1994: 525f.) emphasizes the preference for bimoraism, arguing that the optimal foot (a full, 'closed' foot in his terminology) consists of precisely two moras. Thus a closed foot can be formed by a single heavy syllable, or by two light syllables - but not by a light syllable followed by a heavy one. He allows for words like cyning ${ }^{8}$ 'king' to be grouped into a prosodic unit, but of a less optimal sort than a typical bimoraic foot. Specifically, he posits two stages: one in which the initial syllable stands on its own as a degenerate, open foot, [cy[.ning]; and a second where an initial degenerate foot is merged with a following normal one to create a single longer foot, [cy.ning] Idsardi (1994: 526).

Idsardi's (1994) method of building Old English feet has two advantages. First, it allows trimoraic (or heavier) sequences only in the initial feet of words: all others must be precisely bimoraic. In other words, the resolution of a sequence like cyning is less automatic than in wine 'friend', and only allowable in initial feet. Second, it presents feet as simple units, either as a syllable or a resolved sequence of two syllables, creating a much more straightforward and typologically normal foot structure than the multi-branching 'Germanic foot'. However, there are some features of Idsardi's analysis that are less desirable. The proposal of unpaired

\footnotetext{
${ }^{7}$ Dresher and Lahiri (1991) cite (1d) as $h \bar{e} a f(u) d u$, with the parenthetical signalling dialectal variation. In particular, they refer to a rule proposed by Dresher ([1978] 1985: 142-5) that gives final inflectional $-u$ a special status in the West Mercian of the Vespasian Psalter (PsGl(A)), which accounts for the exceptional forms héafud and hēafudu found there (Dresher \& Lahiri 1991: 280, n. 23). Leaving aside this special Mercian rule, their theory predicts the forms as given in (1).

${ }^{8}$ This word is not used by Idsardi as an example. He, like other theorists, makes much of the supposed high vowel loss in the NOM.PL of fareld 'journey, course', held to be fareld < *fareldu (cf. Dresher \& Lahiri (1991: 257f.)). However, although an earlier endingless plural *fareld may be plausible, such a form is nowhere clearly attested. The suffixed form fareldu is found several times, though under most views this is a late, analogical creation. On the attestation, see Cameron et al. (2007: s.v. fareld, farelt).
} 
left and right brackets, which are assigned independently and according to rather different rules, may be unnecessary theoretical apparatus. He also holds that final consonants are extrametrical, which is almost certainly wrong as a general rule and leads to various complications of his model. And lastly, Idsardi's rule for high vowel deletion is essentially a restatement of the approach going back to Keyser \& O'Neil (1985): in his terminology, a high vowel deletes after a metrical closure, that is, after a foot (Idsardi 1994: 526). ${ }^{9}$

\section{LACK OF ORIGINAL SYNCOPE OF HEAFUDU}

We have seen that a number of theorists have attempted to describe syncopated heafdu under the assumption that this is the phonologically regular form of this word. Much recent work, however, has shown that the oldest form of this word is most likely heafudu, with preservation of both final vowels (Bermúdez-Otero 2005b: 32-4; Fulk 2010). The attestations of *héafudu show considerable variation, with héafudu, hēafdu, and héafod all occurring (with further variation between $u$ and $o$, and sometimes occurring with a distinct ending $-a$ ). The only form to be attested in all dialects is heafudu, and within each dialect it generally has the appearance of an archaic form.

In the early Mercian of the Vespasian Psalter, for instance, héafud is attested five times, and héafudu twice. Later, in the Mercian portion of the Rushworth Gospels (Ru1), heafod alone is found, a pattern which suggests this form is an innovation that was beginning to displace héafudu already in earlier Mercian. A similar distribution is found in West Saxon: syncopated héafdu (along with the variant héafda) dominates in the later language, but unreduced héafudu does occur once in the relatively early Alfredian Cura Pastoralis (CP) (Fulk 2010: 137). Although the syncopated form is often cited as a regular development, it is mostly restricted to this one dialect, and its displacement of earlier héafudu seems to closely parallel the rise of plural héafod in Mercian. ${ }^{10}$

Aside from this suggestive distribution, both hēafdu and heafud can be readily explained as analogical formations: the former has regularized syncope by extending it from the dative and genitive forms, heafde, héafdes; the latter has adopted the widespread pattern of heavy neuter plurals that are identical to their singular forms (Bermúdez-Otero 2005b: 27-30; Fulk 2010: 138). Unreduced héafudu, however, is much more difficult to explain as a plausible morphological creation. Even if syncope were removed analogically in an original *héafdu $\rightarrow$ $h \bar{e} a f u d u$, this ought to have affected the whole paradigm equally, not just the NOM.-ACC.PL, and we find no comparable unsyncopated datives or genitives in early or non-West Saxon texts. ${ }^{11}$

Further evidence for lack of high vowel loss in words of this shape comes from adjectives such as $l \bar{y} t e l$ 'little', which in the FEM.NOM.SG and NEUT.NOM.-ACC.PL has the form ly telu< *lȳtilu throughout Old English. Much like with heafod, this lack of syncope contrasts with

\footnotetext{
9 Earlier in his analysis Idsardi (1994: 525) proposes a different view, that all unparsed (unfooted) high vowels are lost before choosing to favour the conditioning of a closed bracket. I believe the earlier, passing view to be more correct, as will be argued below. Halle et al. (1993), in their response to Dresher \& Lahiri (1991), similarly suggest deleting unfooted high vowels, but their approach requires a great deal of stipulation in order to create the necessary metrical groupings. As will be discussed below, the complications for all these theories seem to result primarily from attempting to analyse a system that originated in early Old English according to the phonology of the later language.

${ }^{10}$ The late Northumbrian Lindisfarne Gospels ( $\mathrm{Li}$ ) also have a syncopated hêafda, but only when the ending is the unhistorical, non-high - $a$. Bermúdez-Otero (2005a: 3-4) suggests that the southern Northumbrian portion of the Rushworth Gospels (Ru2) may have also had a syncopated *hêofdo, on the model of the similarly shaped noun for 'devil': NOM.-ACC.PL dīowlo, dīowla, alongside dīowulo. However, only unsyncopated hēofodo and hēofud (this latter probably a Mercianism) are actually attested in this text, and the parallelism with défol - a borrowed word with a distinctive and theologically motivated gender alternation between the singular and plural - should probably not be pressed (cf. Hogg and Fulk 2011: 141 (section 3.138)). There are unfortunately no early Northumbrian attestations of the plural of heafud.

11 A few restored examples of DAT.SG hēafode and GEN.SG hēafodes are found, but only in very late West Saxon texts of the 11 th and 12 th centuries. Unsyncopated DAT.PL ${ }^{\times}$héafodum and GEN.PL ${ }^{\times}$hêafoda are completely unattested.
} 
other case forms, e.g. FEM.DAT.SG $l \bar{y}$ tle, in a paradigmatic alternation which is very difficult to account for as the result of secondary morphological processes.

If we also turn to some of the very earliest preserved Old English, the Épinal and Erfurt glossaries (EpGl and ErfGl), we find two examples of FEM.NOM.SG forms that show no syncope, and are difficult to explain as the result of analogy. They are hirnitu ${ }^{12}$ 'hornet' and aelbitu ${ }^{13}$ 'swan'. The earliest history of the latter is not entirely clear. It most likely originally inflected as a consonant stem, as evidenced by the occasional Norse plural elptr $<*$ albitiz (Noreen [1923] 1970: 284), and in later Old English it is found as both an $\bar{o}$-stem and a jon-stem (NOM.PL ylfettan). The best explanation is that this word was remodelled at an early date from a consonant stem to an $i$ stem, which is its more usual inflection in Norse (plural alptir). In English, all light $i$-stems were shifted early on to the $\bar{o}$-stems, e.g. *frami 'advantage' $\rightarrow$ fremu, a change which could easily have taken an early *albiti with it, giving the attested aelbitu (Pheifer 1974: 1xxxv (section 77); Hogg and Fulk 2011: 43 (section 2.66)). This development naturally requires the word, whether * clbiti or *albitu, to be unaffected by either syncope or apocope.

By all appearances, hirnitu is a normal feminine $\bar{o}$-stem from *hurnitu, an exact match for its Old Saxon cognate horneta. Again, it is difficult to see how such a form could be a secondary remodelling from ${ }^{\times}$hyrntu, ${ }^{\times}$hyrnt, or ${ }^{\times}$hyrnit. It should be noted that the stem-class of this word is not entirely stable, since it is found in later Old English as a jo-stem (e.g., ACC.PL hyrnetta). Because of this, it has been suggested that the $\bar{o}$-stem forms are secondary, despite their age (Luick 1921: 286 (\$ 307)). However, given the Old Saxon cognate and the early date of the glossaries, it seems more likely that hirnitu is what it looks like: the straightforward continuation of Ingvaeonic *hurnitu (Dahl 1938: 118f; Hogg \& Fulk 2011: 34 (section 2.47.4)).

Taken together, these considerations strongly suggest that any theory of high vowel loss should aim to describe $h \bar{e} a f u d u$, not syncopated héafdu or any other form, as the regular phonological outcome. A fuller range of attested forms, along with the patterns of morphological change that have partly obscured the data, will be discussed below in section 7 . For now, it is enough to note that it is difficult to account for these old forms and the morphological alternations of héafudu, lytelu with héafde, lỳtle as secondary or analogical.

\section{Early Old English foot structure}

In investigating Old English foot structure, we can start by focusing on the paradigmatic syncope in the various case-forms of he्afud, such as the contrast between the archaic NOM.PL héafudu and the syncope always found in DAT.PL héafdum. This alternation can be accounted for, both in terms of foot structure and the rule for vowel deletion, at an early stage of Old English, while there was still a distinction between short and long vowels in unstressed syllables. The basic principle for the foot structure is, as has long been recognized, to form moraic trochees from left to right: starting at the beginning of the word, syllables are grouped into bimoraic units (Keyser \& O'Neil 1985: 6; Hutton 1998: 188ff; Bermúdez-Otero and Hogg 2003: 111; Bermúdez-Otero 2005b: 8). These feet, as Idsardi has emphasized, should be precisely bimoraic, not simply minimally so. If footing a syllable would make it have more than two moras, that syllable is left unfooted. The only exception is that the initial syllable must be footed, and a trimoraic (or heavier) foot can be formed to accommodate it if necessary. Degenerate, monomoraic feet are not allowed in simplex words, though metrical evidence in the following section suggests they may perhaps arise in compounds. Together, these two main principles - the formation of precisely bimoraic feet, and the overriding

12 Erfurt 275; spelled hurnitu in Corpus (CorpGl) 603.

13 Épinal 718; so also Corpus 1439. Erfurt has abitu for celbitu. 
requirement to foot the initial syllable - account well for resolution, and allow high vowel loss to be described in simple and natural terms: high vowels are lost when unfooted.

When a single high vowel follows a heavy stem, its loss is very straightforward. The NOM.PL of word would originally have been footed as *[wor].du, with the first syllable forming a full bimoraic foot on its own. The second syllable was too light to form a second foot, and so remained unfooted and eventually deleted. Similarly, in *[we.ru].du the first two syllables would comfortably resolve into a bimoraic foot, leaving the vowel of the third to be deleted. In bimoraic words, for example, *[fa.tu], the grammatical ending is part of the initial foot, protecting it from loss.

Heavy stems followed by more than one syllable show a more variable development, depending on the weight of final inflectional syllables. The NOM.-ACC.PL of heafod would form two bimoraic feet, [hēa][.fu.du], protecting both vowels from phonological loss (cf. BermúdezOtero 2005b: 30-2). Things worked differently in, for example, the DAT.PL *heafudum. While the first syllable would still form a single bimoraic foot, the two unstressed syllables could not resolve, since this would form a trimoraic unit. So the medial syllable was simply left unfooted, and the final syllable formed another bimoraic foot. This difference in foot structure, NOM.PL *[hēa][.fu.du] versus DAT.PL *[hēa].fu[.dum], explains why syncope occurs in the latter but not the former.

This explanation also accounts for the otherwise puzzling difference between he्efudu, with both vowels retained, and DAT.SG he्efde, which has lost its middle vowel. The DAT.SG ending was, in contrast to the NOM.-ACC.PL, historically long: early Old English $*-\bar{\alpha}<$ PGmc $*^{*}-a i$. Before the loss of quantitative distinctions in unstressed vowels, this ending would therefore have been heavy, like the DAT.PL -um, meaning that syncope in *[hēa].fu[.d $\bar{\alpha}]$ was entirely regular. See (2) for the full pattern of syncope across the inflection of héafod.

\section{Early Old English Later Old English}

SG.

\begin{tabular}{|c|c|c|}
\hline Nom.-Acc. & *[hēa][.fud] & $>$ heafod \\
\hline Gen. & *[hēa].fu[.dæs] & $>$ hēafdes \\
\hline Dat. & $*[$ hêa].fu[.d $\bar{x}]$ & > hēafde \\
\hline PL. & & \\
\hline Nom.-Acc. & $*[$ hēa $][. f u . d u]$ & hēafudu \\
\hline Gen. & $*[$ hēa].fu[.dā] & $\bar{e} a f d a$ \\
\hline Dat. & *[hēa].fu[.dum] & \\
\hline
\end{tabular}

Previous attempts to develop a foot structure similar to this have run into complications, attempting to account for this difference between $-u$ and the other vocalic endings in terms of the phonology of later Old English, without recourse to historical length distinctions. Halle et al. (1993: 533), for example, stipulate that DAT.SG -e is metrically invisible; Bermúdez-Otero (2005b: 34 ) ascribes the difference in syncope to $-u$ alone being a stem-level suffix, while other endings are word-level. Some form of this latter analysis might well be correct for later Old English, which is Bermúdez-Otero's focus, with this distinctive behaviour of $-u$ being a later reflection of its status as a short vowel in early Old English: the morphological distinction of later Old English is best seen as a response to patterns of syncope whose conditions became unclear after unstressed vowel shortening.

There are two phonological complications which need to be addressed. The first is the issue of secondary stress. If the final syllable of *héafude really constitutes a separate foot, then should it not have a secondary stress? To avoid this, Bermúdez-Otero (2005b: 15ff.) suggests that final syllables cannot be footed. This leads him to restrict high vowel deletion to affect 
light unfooted syllables only, leaving, e.g., the second syllable of hēafod as unfooted, but undeleted due to its weight. I would suggest that it is simpler to assume the foot structure proposed here, but to follow this with a straightforward destressing of at least most final feet (Dresher \& Lahiri 1991: 260f.).

A related question is whether final consonants were, or could be, extrametrical. Idsardi (1994: 526f.) assumes a universal extrametricality of final consonants, largely motivated by the desire to avoid a secondary stress in a word like heafod: if the final consonant does not count, the syllable cannot form a foot and so will be unstressed. Although he had initially suggested a rule of high vowel deletion like the one offered here, he rejects this in part because of the complications caused by his rules of final consonant extrametricality. Again, these complications and revisions become unnecessary under the assumption that final feet were created, and had real phonological relevance for high vowel loss, but did not surface bearing stress.

There may, however, be some reason to assume a limited form of extrametricality, applying selectively when necessary to achieve a satisfactory foot (such variable application is suggested by Bermúdez-Otero 2005b: 9). The clearest cases are heavy derivational elements that appear to regularly bear metrical ictus, such as the agentive suffix -end, even when word-final (see Russom 2001: 55-63, for a discussion, with references, of the metrical evidence). This is anomalous in two ways under the foot structure proposed here: the suffix seems to be footed despite being trimoraic, and stressed despite being final. Extrametricality of the final consonant may account for both these anomalies. If a word such as ridend 'rider' has the foot structure [ri1][.den]d, the parsing of the final $-d$ as outside the foot structure would bring the second foot down to weight (63), and may also protect the second foot from final destressing (either because the foot is no longer truly word-final, or because the application of a marked process to obtain an optimal foot protects that foot from later destressing). It is important to emphasize that final consonant extrametricality does not seem to have been a universally available option, or we would expect a full parse of, e.g., DAT.PL *héafudum as ${ }^{\times}\left[\right.$hēa][.fu.du]m $>{ }^{\times}$heafudum rather than correct $*[$ hèa].fu[.dum] $>$ heafdum. Since the evidence for the footing of suffixes like -end comes entirely from derivational elements, extrametricality may be at least in part limited by the morphological status of the suffix (Hutton 1998: 124-9; Bermúdez-Otero 2005b: 9, 29f.). It is also possible that strategies for footing syllables are applied sequentially, with resolution attempted before extrametricality.

This rule of extrametricality is also limited with regard to initial syllables, in large part because the tolerance of initial feet with more than two moras makes more widespread extrametricality unnecessary. To insist on bimoraism in initial feet would result in needless complications. Old English has a large number of monosyllabic words with three or more moras, and words such as lèoht 'light', frēond 'friend', and torht 'bright' could only be made bimoraic by assuming the extramtricality of multiple consonants. There seems to be no reason to assume these words were phonologically exceptional, and we even find some new overheavy words created through metathesis, such as forst 'frost' $<*$ frost. ${ }^{14}$ We also find resolved overheavy feet in words like cyning, where the requirement to foot the initial syllable takes precedence over the bimoraic preference. ${ }^{15}$ Further examples of trimoraic initial feet in polysyllables can be found in hâtte 'is called', and in various morphologically

\footnotetext{
14 Against this, there are examples of overlong syllables being shortened, e.g. godspell 'gospel' $<*$ gōd-spell (Ringe \& Taylor 2014: 281-283). A preference for precise bimoraism appears to have been stronger at an earlier stage of Germanic, as suggested by various shortenings of overlong syllables by Osthoff's law.

${ }_{15}$ There are numerous examples of this word being resolved in poetry, e.g. Jeah pe se yldra cyning 'though their elder king' (Ex 141a).
} 
more complex examples such as cwealmness 'torment' or the MASC.ACC.SG adjective goldne 'golden'.

To sum up, the workings of early Old English foot structure and high vowel loss were originally very straightforward, and are given in (3-6).

(3) Feet are formed from left to right, grouping syllables into bimoraic units.

a. The first syllable must be footed, even if this creates an overheavy foot of more than two moras.

b. Otherwise feet are strictly bimoraic.

c. Non-initial syllables that cannot be accommodated within this process are left unfooted.

(4) If a syllable has not otherwise been footed, a final consonant may optionally count as extrametrical, if necessary to allow the creation of a bimoraic final foot.

(5) Unless followed by an extrametrical consonant, final feet are destressed.

(6) Unfooted high vowels are deleted.

This is the system specifically for 'early' Old English, lasting until the loss of length distinctions in final unstressed vowels. Just when this shortening took place cannot be given in precise terms, but we can give a rough chronology. Generally speaking, there is good independent reason to suppose that high vowel loss originally predates the shortening of unstressed vowels. For example, there is no loss of the high vowel in NOM.-ACC. SG $r \bar{c} c e<* r \bar{\imath} \bar{\imath}$, which is most easily explained if the vowel was still long when high vowel deletion was a regular phonological process (see 7.2 for a fuller discussion of this inflectional class). The evidence of Kaluza's law, discussed in the next section, also suggests that there were still unstressed long vowels when Beowulf was composed (or at best not long before), suggesting that this phonological distinction was preserved nearly up to the historical period, if not into it. A precise terminus a quo for Beowulf is difficult to establish, but Fulk (1992: 390), in his exhaustive treatment of the dating Old English poetry, considers a date before c. 685 to be 'considerably less probable'. How long after this the shortening occurred is impossible to say with any certainty, and there may well have been variation from dialect to dialect. The best positive evidence that long vowels were shortened comes from the mergers of unstressed $\breve{l}$ and $\breve{\breve{a}}$ as $e$. Fulk (1992: 351-62, 386-90, with references), who reviews this evidence thoroughly, concludes that this merger happened no later than the mid 8th century south of the Humber, and the mid 9th in Northumbrian, suggesting that unstressed vowel length had been eliminated some time before this. How long before is unclear. He reckons that shortening must predate this merger by at least a generation, meaning that the shortening must have occurred by roughly 725 in the southern dialects, and by 825 or so in Northumbrian. Taking these pieces of evidence together, we can assume that unstressed long vowels were shortened south of the Humber very roughly around the year 700, give or take several decades, and with due allowance for possible further dialectal variation (cf. also Ringe \& Taylor (2014: 302f.), who date the change to the late 7 th century).

\section{KaluzA's LAW AND THE EVIDENCE OF METRE}

This view of early Old English foot structure is interestingly congruent with the metrical phenomenon known as Kaluza's law, observable primarily in Beowulf. The rule, as classically 
formulated by Fulk (1992: 153-68, 381-90), determines whether or not a secondarily stressed element is resolved or counts as two metrical positions. Contrasting examples are: ${ }^{16}$

(7)
a. bānfatu bærnan
bone-vessels to-be-burned
'bone-vessels to be burned' (Beo 1116a)
b. mundbora wæs
protector was
'was a protector' (Beo 2779b)

In (7a), -fatu must be resolved, since verses of the shape / / $\backslash$ $\mathrm{x}$ are otherwise unattested: there are no verses like ${ }^{\times}$sāncessas sìde (Sievers (1893: 133 (section 85.2)) and Cable (1974: 81); cf. Beo 223a). ${ }^{17}$ In (7b), -bora must have disyllabic value, or else the verse would be too short. That is to say, (7a) and (7b) must be scanned as equivalent to (8a) and (8b), respectively:

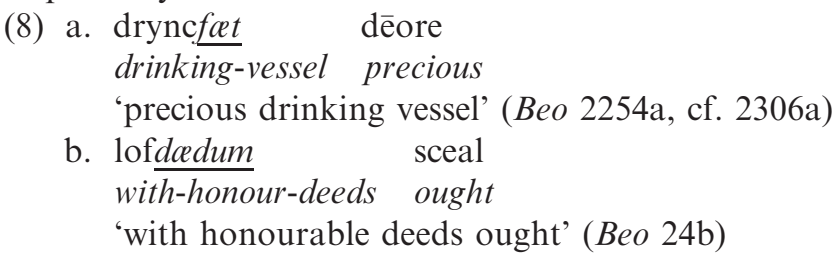

The alternatives, either assuming non-resolution in (7a) or resolution in (7b), result in unparalleled, unmetrical verse patterns.

From the perspective of later OE phonology, this difference in resolution between (7a) and (7b) appears puzzling and arbitrary, but is very easy to describe at a stage when there was still a distinction between long and short unstressed vowels. The resolved form -fatu would have had the same form even in prehistoric Old English, *fatu, while the second vowel of -bora was long, *borā. This pattern of resolution or its failure in these words seems to precisely parallel the foot structure proposed here: *fatu is bimoraic, and is resolved; *bor $\bar{a}$ is ineligible for resolution since that would result in a trimoraic unit. This distinction applies only in certain metrical positions - classically described as those under secondary stress - and in a full lift any word beginning with a light syllable must be resolved, however heavy the resulting sequence is. We have already seen the example of cyning in note 5 above, and in Beowulf words like guma 'man' < *gumā resolve under main stress just as readily as fatu; only under secondary stress do the two types show any distinction.

\footnotetext{
16 The basic data for Beowulf can be found in Bliss (1962: 27-30), supplemented by Fulk (1992: 160-2), all expanding on the observations of Kaluza (1896: 125ff.). Many useful lists can also be found in Suzuki (1996a). For the fundamentals of Old English metrical study, and explanations of the terminology and labelling used here, see Sievers (1893: 22-36) and Terasawa (2011: 27-62).

${ }^{17}$ This restriction may be accounted for in several ways, depending on one's favoured metrical theory. Under a traditional Sieversian view, such a verse is ruled out for having five positions. There are, to be sure, a number of $\mathrm{D}^{*}$ verses which have five positions, but this is the only such type allowed (either as an archaism preserved in limited contexts by tradition (Sievers 1893: 183 (section 154.1); Yakovlev 2008: 66-8), or with the extra position resulting from a beat created by two adjacent, clashing lifts (Cable 1974: 80f; 1991: 138-43; , Suzuki 1992; 1996b: 29-30). The word-foot theory rules out such verses through strict constraints on 'reversal'. If two word-feet are of unequal weight, the lighter foot will normally come first, the heavier second. When a verse is of normative weight, the order may be reversed, but this increases the metrical complexity of a verse considerably. This is why verses like sunu Healfdenes 'Healfdene's son' are more frequent than Healfdenes sunu. Verses of greater weight than normal, such as sīde sāencessas (Beo 223a) are already relatively complex and rare, making them ineligible for reversal (Russom 1987: 2831). Whichever theoretical motivation one prefers, it seems to be an empirical fact that verses like ${ }^{\times}$sannassas sìde do not occur, and it follows that in verses like Beo 1116a the second element, -fatu, has the value of a monosyllable rather than a disyllable.
} 


\subsection{Kaluza's Law and Long Vowels}

As with phonological feet, Kaluza's law can be straightforwardly described in terms of mora counts ${ }^{18}$ - but in both cases, only if we work with the long and short vowels of a very early stage of Old English. Precisely how to determine whether an unstressed vowel is long or short in early Old English is not always immediately obvious. Traditionally the length of a vowel in early OE is framed in terms of whether or not it was 'trimoraic' (or 'circumflex') in Proto-Germanic:

An inflection is long [in Beowulf] if (1) it ends in a consonant in Old English, or (2) the form reconstructed for Proto-Indo-European or Proto-Germanic is written with a circumflex accent, in actuality probably representing disyllabic pronunciation in ProtoGermanic (Fulk 1992: 419).

It is, however, somewhat misleading to frame the early OE situation in terms of ProtoGermanic vowel distinctions, or to relate early OE bimoraic vowels too directly to PGmc trimoraic vowels. The Proto-Germanic situation is only relevant insofar as trimoraic vowels tended to be reduced less in Northwest and West Germanic and so appear as bimoraic in early OE, while PGmc bimoraic vowels were, in absolute auslaut, typically shortened to become monomoraic in prehistoric OE. ${ }^{19}$ But it is certainly not the case that all long vowels in early Old English were necessarily formerly trimoraic, since word-final bimoraic vowels could retain their length when protected by a consonant that later disappeared.

Rather than a straightforward one-to-one mapping with any single Proto-Germanic category, such as 'trimoraic vowels', the long vowels of early Old English must be arrived at through linguistic reconstruction. In many cases it is relatively straightforward to determine whether a vowel was long or short during this time. A number of short endings preserved a PGmc short vowel, such as the $i$-stem MASC.ACC.SG $*_{-} i^{n}>*_{-}-i$; or, with loss of final $*_{-} z$, the corresponding NOM.SG *-iz $>*_{-}-i$. In $w a$-stems, the final vowel was lost in West Germanic, and the $* w$ was vocalized into a short vowel. Proto-Germanic bimoraic vowels in absolute auslaut were also shortened, such as the $*_{-} \bar{o}$ of the NEUT.NOM.-ACC.PL $a$-stems and the FEM.NOM.SG $\bar{o}$-stems, which became $*-u$. The origins of long endings are also various. Final diphthongs remained long vowels, although they were often monophthongized, as in the strong adjective MASC.NOM.PL ending $*-\bar{p}<*$-ai $(\leftarrow$ PIE pronominal $*$-oi $)$. The most common final long vowels come from final 'trimoraic' vowels, such as the $n$-stem MASC.NOM.SG ending $-\bar{a}<*-\hat{o} .{ }^{20}$

There are, however, cases which are considerably more difficult, such as the NOM.PL $i$-stem ending, which is written -e in later Old English. It originally developed from PIE *-eies, and by regular sound change became first pre-Gmc *-ijiz and then PGmc *-iz (parallel to the development of the $e$-grade forms of class I weak verbs). Because this development involved the

18 There have been some alternative proposals, suggesting either that the law rests on a different phonological (or partly morphological) basis (Suzuki 1996b: 205-33; 1996a) or that it is not at heart a phonological process at all (Weiskott 2012). None of these alternatives is entirely compelling; see the rebuttals of Fulk (1998, 2007) and Neidorf \& Pascual (2014). There has also been some discussion about whether Beowulf itself was composed while the phonological distinction was still active, or whether its apparent adherence to the law is due rather to its traditional character, echoing an older state of the language in its formulae (Hutcheson 2004). This particular debate about dating is not immediately relevant to the current discussion, since even if Beowulf is a later poem (which is on the whole unlikely), the formulaic system still reflects the early Old English phonological system.

19 The original phonological status of 'trimoraic' vowels is therefore not immediately relevant to Kaluza's law. Fulk suggests disyllabic pronunciation (Fulk 1992: 153f., n. 2; Hogg \& Fulk 2011: 11, n. 2), but there is a good argument to be made such vowels were actually overlong and trimoraic (Jasanoff 2002). However it may be, the important feature is that they were less prone to shortening than plain long vowels.

${ }^{20}$ For further details, see Fulk (1992: 419-25), as well as the standard handbooks of Germanic philology, e.g. Ringe (2006), whose reconstructions I generally follow here. Some, such as Boutkan (1995), do not reconstruct a separate category of trimoraic vowels at all; this perspective does not have any particularly significant ramifications for the length of vowels in early Old English. 
contraction of two syllables, Fulk assumes that it was trimoraic in Proto-Germanic (1992: 421), though there is no particular evidence that this was the case. Indeed, there is no comparative evidence for any trimoraic vowels other than $* \hat{e}$ and $* \hat{o}$ (Stiles 1988: $126 \mathrm{ff}$.). ${ }^{21}$ This vowel does indeed seem to have remained long into the West Germanic languages, but this is simply because the final $*_{-} z$ protected the (bimoraic) $*_{-\bar{l}}$ - from the earliest Northwest Germanic shortenings of absolutely final vowels (Ringe \& Taylor 2014: 14f.). Unapocopated forms like OE Myrce 'Mercians' $<*$ markizz and OS gesti 'guests' $<$ *gastīz attest to the retained length of this ending well into the separate histories of these languages. The only suggestion of special behaviour comes from Old High German, where the ending seems to have been shortened earlier than other unstressed long vowels (Braune 2004: 201 (section 215, n. 4)). Since this German shortening was probably at least partly morphological, and since the analogical pressures involved would have been weaker in English (Prokosch 1939: 246), the historical-phonological expectation is that this ending should still be long at the time of Beowulf.

This expectation seems to be borne out by three verses in the poem, 116b, 1279b, and $2479 \mathrm{a}$, in which resolution is suspended (though these verses' type, Sievers's type C, provides less reliable evidence for the law; see section 6.2). The only possible exception is line 1122a läðbite līces 'terrible bite(s) of the body', in which bite must be resolved. If this really is a NOM.PL, then it would seem to violate Kaluza's law: resolution under secondary stress would create a trimoraic unit, *lāðbitī līcas. Fulk (1992: 421) takes the verse so, and presents it as evidence of German-like shortening in early Old English. But the grammatical interpretation of the verse is unclear and -bite need not be in the plural (Tolkien 1982: 113; Fulk et al. 2009: 187, n. 1121f.). If nominative singular, bite $<*$ biti $<*$ bitiz would be short and therefore straightforwardly bimoraic in early Old English.

This range of distinctions and problems seems to be precisely the same for both Kaluza's law and early Old English foot structure. In both cases, later Old English endings, in particular the ubiquitous $-e$, have obscured a variety of older distinctions. The precise correlation with older quantitative distinctions, even varying from inflection to inflection within the same lexeme, places both the foot structure and the metrical law at an early stage of Old English, before the relevant length distinctions were lost. That is, both metre and foot structure rest on the same phonological basis, and each reinforces the other in pointing to the system of unstressed vowels of early Old English.

\subsection{Phonology and Metre}

The parallels between Kaluza's law and early Old English foot structure seem to go beyond a common basis in early Old English quantitative distinctions, since both rely on a common principle. Both involve the combining of syllables to create bimoraic units; overheavy units are only allowed at the highest level of stress or ictus. The exact relationship between metre and phonology is, however, not perfectly clear. To some extent, such as in the unresolvability of mundbora, the metrical system may simply reflect the phonological foot structure.

\footnotetext{
21 The only possible shred of evidence for a trimoraic * $\hat{\imath}$ in PGmc is the imperative of heavy class I weak verbs in Gothic, such as sōkei 'seek'. Normally final $*_{-} \bar{\imath}$ is shortened to $-i$ in Gothic (e.g. bandi 'bond' $<*$ band $\bar{l}$, or $q \bar{e} m i<$ $* k^{w} \bar{x} m \bar{\imath}$ 's/he should have come'), but in this form it seems to have retained its length. It is, furthermore, a contracted form, from PIE *-éie. However, in some Germanic languages this form is found with shorter forms that suggest an original bimoraic vowel, namely $\mathrm{OE} s \bar{e} c$, ON sǿk, neither of which show any indication of an overlong ending. The imperative of Gothic class I weak verbs is also unusual in having the same long ending also for short-stemmed verbs, e.g. nasei 'save', where it can have no historical justification: the PGmc form should have been *nasi <*nasji, shortened by the converse of Sievers's law like all other reflexes of PIE *-eie after short-stemmed words (Ringe 2006: $121,176)$. This imperative ending is an interesting problem, but a poor basis on which to reconstruct a phoneme $* \hat{\imath}$.
} 
Insofar as this is the case, the metrical system may be able to offer some further evidence about the workings of Old English foot structure. There is little direct phonological evidence available regarding the structure of compound words, for instance. The suspension of resolution in words like mundbora indicates that the second element of a compound did not have the same licence as the primary lexical head to create a trimoraic sequence. At the same time, it is unlikely that such second elements were left unfooted and wholly unstressed - indeed, the metrical evidence precludes this. This suggests that it was possible, at least for the heads of second elements of compounds, to create a degenerate, monomoraic foot. If this is so, then we should add an extra rule to the foot formation rules in (2) above:

(9) If the head of the second element of a compound would be left unfooted by the above rules, it instead forms a degenerate, monomoraic foot.

Such a rule implies that Old English foot structure depends on a set of sometimes competing preferences. Bimoraic feet are the optimal prosodic unit. Overlong units are also tolerable, but only in initial syllables. Otherwise syllables are either left unfooted or put into degenerate feet, depending on whether or not they constitute a lexical head.

Other aspects of resolution in poetry are more questionable, and may or may not reflect a more specifically metrical dimension to resolution. Particularly interesting is the suspension of resolution at the beginning of an independent word. Although Fulk's classical formulation of Kaluza's law specifies that it applies only under secondary stress, the law also appears to apply to any position immediately following a heavy stressed syllable (this is in keeping with Yakovlev's (2008: 76) recent argument that there is no meaningful distinction between primary and secondary stress in Old English metre). Thus we find a contrast between the following two verses, with the resolution suspended in the overlong cyninges, but allowed in the bimoraic apelinges. Both of the verses in (10) have the same Sieversian scansion, $/ / \backslash \mathrm{x}$ :

(10) a. feorh cyninges

body/life of-king

'the body/life of the king' (Beo 1210b)

b. feorh æpelinges

life of-prince

'the life of the prince' (Beo 2424a)

If we were to assume resolution in (10a), the verse would have only three metrical positions; suspension of resolution in (10b) would give the verse five positions. It is difficult to say whether this is a purely metrical phenomenon (Fulk 1992: 239ff; Cable 1994), or reflects otherwise unrecoverable facts about Old English phrasal prosody, since the only evidence comes from poetry. ${ }^{22}$

Further complications come from possible exceptions to or limitations on the law. Under Fulk's (1992: 157-9) view, the law applies with full regularity only in certain metrical types, namely A2 verses with a resolved second position and D verses with a short penultimate syllable. In other metrical contexts, Kaluza's law seems to hold as a rule of thumb, but with a considerably larger number of exceptions. Out of 260 type $\mathrm{C} 2$ verses (that is, type $\mathrm{C}$ verses

\footnotetext{
22 Because the precise conditioning of Kaluza's law remains unclear in the published literature, I refrained above from offering a concise statement of the law. I discuss the matter at greater length in my D.Phil. thesis, which is still forthcoming at the time of this writing, where I suggest the following definition of Kaluza's law: when immediately following a heavy syllable, a short syllable bearing some degree of stress resolves with the following syllable if, and only if, the result is a precisely bimoraic unit. This formulation suggests that sequences of immediately adjacent stresses in the metrical system were treated much like compound words, with trimoraism allowed in the first such lift alone.
} 
with a short penultimate syllable) in Beowulf, Hutcheson (2004: 309-11) finds that Kaluza's law applies $87.3 \%$ of the time, with 33 exceptions. ${ }^{23}$ The proportion of verses following the law is high enough to suggest that in these unresolved sequences a heavy ending is preferred, but the exceptions are frequent enough that they can hardly be disregarded as errors. It seems that the Beowulf poet was, at least on occasion, willing to suspend resolution even in bimoraic sequences.

It is both interesting and important that essentially all the verses not conforming to Kaluza's law break it in very particular ways: they suspend resolution when we would expect it, and furthermore do so only verse-finally. Exceptions of other possible sorts, either resolving trimoraic sequences when they should be suspended, or failing to resolve a bimoraic sequence verse-internally, are vanishingly rare. ${ }^{24}$ That violations of Kaluza's law are limited according to metrical contexts may suggest that these 'exceptions' are licensed in some way by the poetic system. Specifically, the metre seems to have tolerated a certain amount of deviation from the strict phonological basis for resolution, but only in the direction of increasing equivalence of syllables and metrical positions: metrical positions remained closely rooted in phonological units, just of a different sort. Deviating in the other direction, applying resolution when it was not phonologically justified, is so rare that we should probably regard it as disallowed.

That poetic resolution may have some purely metrical dimensions should not obscure the strong parallels that Kaluza's law and early Old English foot structure provide for each other. That both processes depend on the same set of vowel length distinctions, regulated in much the same way, suggests that we have an example of metrical and phonological theories supporting each other. Together, they give a coherent view, in the sense of Dresher \& Lahiri (1991), of early Old English, with phonological foot structure providing a basis that is echoed, and perhaps elaborated upon in the metrical system. After the shortening of unstressed long vowels, both these phonological and metrical dimensions were disrupted. Resolution continued to play a role in poetry even into Middle English (Fulk 2002), but the detailed operation of Kaluza's law is not discernible outside of Beowulf.

\section{REWORKINGS OF HIGH VOWEL DELETION}

The early Old English foot structure proposed here makes a specific claim about what vowels were originally affected by high vowel loss on a phonological basis. A core of evidence for this, including the archaic distribution of heafudu and its morphological alternation with syncopated heafde, has already been presented in section 4 , but other forms require more comment. There are, generally speaking, two important points to make: firstly, that the evidence cited in section 4 cannot be explained as secondary under any other view of high

\footnotetext{
23 The precise statements from both Fulk and Hutcheson should be taken with a certain caution. Fulk, for instance, finds that type D adheres to the law so closely only because he has followed Bliss (1962: 70) in, probably incorrectly, reclassifying $1230 \mathrm{~b}$ and $2241 \mathrm{~b}$ as type A2k rather than D. The findings of both also depend, naturally enough, of particular etymological judgements about the length various endings, and different historical-linguistic judgements will alter the precise percentages given somewhat. A fuller consideration of these problems is beyond the scope of this paper, but I discuss the matter further in my D.Phil. thesis. For now, it is enough to note that the findings of Fulk, Hutcheson, and others are very useful, but that too much significance should not be placed on either the specific Sievers's types they highlight, nor on their specific numbers.

24 Only three verses probably show genuine resolution of a trimoraic sequence when we would expect suspension: 330a, 1778a, and 3149a. Other apparent examples are either easily emended, as is 1187a (Kuhn 1939: 193), or involve etymological or textual uncertainties, such as were discussed above for 1122a. There are no examples at all of bimoraic sequences suspended verse-internally. I again refer to my D.Phil. thesis for further discussion.
} 
vowel deletion; and secondly that the evidence cited in favour of other theories is not compelling, and can be straightforwardly explained in other ways.

There are two other general proposals about which vowels should originally have been lost. What might be called the traditional view, predicting syncopated heafdu, has already been mentioned. More recently, Ringe (2002) has argued that there were two phases of high vowel loss, with an early syncope (*hêfudu $>* h \bar{e} a f d u)$ followed by a later apocope (> ${ }^{\times}$heafd); see further section 7.3 below. Both of these proposals have been put forward to account for certain evidence, and involve analogical explanation to account for the forms they do not predict.

To a large extent the arguments involved in comparing these proposals are morphological. What is important is not simply that we find forms like hêfudu, lytelu, and hirnitu, but that these forms are difficult or impossible to explain as restorations from a more worn-down

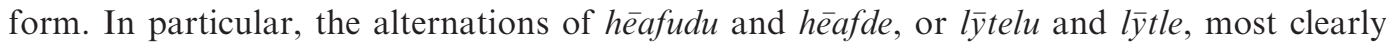
preserved in the Old Mercian of the Vespasian Psalter, deserve a special place in the discussion, as argued by Fulk (2010: 133-6). It is highly unlikely that this morphophonological pattern, which develops regularly under the view of high vowel loss argued for here, would have developed through any means except sound change. Under the traditional view, a pattern of uniform syncope after heavy syllables and before inflections should have developed, hêafdu, hēafde, a pattern which had no reason to be disturbed once established. For Ringe, plural forms such as *ly $t l$ ought to have developed in the same way as originally monosyllabic stems, such as NEUT.NOM.-ACC.PL *wuldr 'glory' (apocopated from *wuldr-u), which develops into wuldur, with no ending but syllabification of the final resonant. On this model, NEUT.NOM.-ACC.PL or FEM.NOM.SG $* l \bar{y} t l$ should have become ${ }^{\times} l \bar{y} t e l$, but this is never found.

The following sections are arranged by type, treating in turn a number of words or categories that have a bearing on the original operation of high vowel loss, and have been cited in support of other theories: the patterns of syncope in disyllabic words like nettenu < *nautinu; neuter plural ja-stems such as ricu; syncopated West Saxon verbs, such as scin $p$ (against Anglian scineð); and feminine abstracts in *-ipu, such as streng $p(u)$.

\subsection{Nètenu, etc}

Closely related to words like héafudu and lytelu are the comparable case forms of nouns like NOM.-ACC.PL nétenu 'animals' (West Saxon nietenu, nȳtenu) and adjectives such gyldenu 'gilded'. Historically these words are distinguished by having an originally long medial vowel: *nautinu and *guldinu. We might expect that the root syllable and the derivational syllable would each form a bimoraic foot, leaving the final $*_{-} u$ unfooted and open to apocope, parallel to $\bar{o}$-stems like eardung 'dwelling' <*ardungu. The simple solution would seem to be that medial vowels were shortened earlier than final ones, so that these words had become *nietinu and *gyldinu by the time of high vowel loss (so Fulk (2010: 129-130, 135)). Against this proposal is the curious fact that the medial syllable never seems to syncopate in West Saxon, as we would expect if the medial vowel were shortened early. We find, for example, GEN.SG nȳtenes < *nīetīnes rather than ${ }^{\times} n \bar{y}$ tnes (cf. syncopated GEN.SG dryhtnes 'lord' $<*$ dryhtinces, whose middle syllable was always short). There is therefore something of a paradox in the West Saxon forms: an unshortened $*_{-}-\overline{-}$ explains the lack of syncope, but should cause the NOM.-ACC.PL to be apocopated ${ }^{\times} n \bar{y} t e n$, while a shortened $*_{-} \check{l}_{\text {- }}$ would account for the preservation of the ending, but leave the lack of syncope unexplained. The oddness of the class increases when we consider the range of OE dialects: this lack of syncope is a West Saxon peculiarity, and in Mercian we do find forms like GEN.PL nètna and DAT.PL gyldnum. 
Ringe (2014: 301f.) attempts to solve the problem through his relative chronology of sound changes: syncope is earlier than apocope, with the shortening of unstressed medial vowels intervening between the two processes of loss. In the NOM.-ACC.PL, *nietinu would fail to undergo syncope because of the long medial syllable, then be shortened to *nietinu in time for the final vowel to be part of a resolved foot and so protected from apocope. This does derive the West Saxon forms correctly, but cannot account for the syncope in Mercian nétna, etc. These Mercian forms would have to be somehow analogical, but Ringe's theory provides no model to introduce syncope analogically into the GEN.PL, *netena $\rightarrow$ netna, without also doing so in the NOM.-ACC.PL, ${ }^{*}$ nētenu $\rightarrow{ }^{\times}$nētnu.

A more traditional alternative, proposed by Luick (1921) and recently revised by Bermúdez-Otero (2005b), holds that word-medial long vowels were shortened early, before high vowel loss, ${ }^{25}$ but retained some property that protected them from syncope. Luick (1921: 290) suggests that the long medial syllable of *nīetinu kept a secondary accent even once shortened. Bermúdez-Otero (2005b: 25-32) argues that this syllable continued to be marked out lexically as being obligatorily the head of a foot, a morphological relic of an earlier time when it was regularly footed on a purely phonological basis. Either variation of this proposal would allow pre-OE *ardungu and *nautinu to have developed different metrical structures by the time of high vowel loss, as shown in columns I and II of (11). Column III shows the lack of syncope in the West Saxon GEN.PL, which contrasts with the Mercian development in column IV (HVD indicates HIGH VOWEL DELETION). ${ }^{26}$

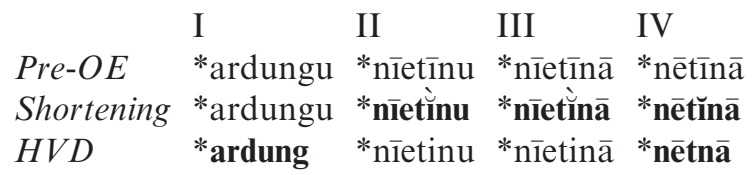

The syncopated Mercian forms would be explained by an earlier loss of or disregard for this special marking, so that the neten type underwent regular high vowel loss and merged at an early date with heafod and lytel pattern. While Luick's (1921) accent can be criticized as an unnecessary phonological entity (Bliss 1962: 113-117 and 24f.), Bermúdez-Otero's (2005b) appeal to the specification of the medial foot on a lexical level seems to be sensible and wellmotivated as a morphophonological phenomenon, giving Luick's idea a firmer theoretical basis.

\subsection{Rīcu and the neuter ja-stems}

The point of departure for the view of high vowel loss in the standard handbooks is the NEUT.NOM.-ACC.PL of $j a$-stems (e.g. Campbell 1983: 146 (§ 353)). Both the early forms and the synchronic surface facts are straightforward. The singular of a word like rice 'dominion' was * ric $\bar{\imath}\left(<\mathrm{PGmc} * r i k i j a^{n}\right)$, with the final vowel surviving high vowel loss. The older plural was

\footnotetext{
25 This relative chronology, with medial vowels shortened before final ones, is supported by metrical evidence. The historically long medial syllables of class II weak verbs count as short in the metre of Beowulf, which is why a verse like 560a préatedon pearle 'they attacked forcefully' scans as having only four metrical positions (Russom 2001: 45f.). The older form *préatödun must have been shortened to *préatadun by the time of Beowulf so that the medial syllable was never footed, and could stand as a fully unstressed syllable in an expanded dip (along with the inflectional ending, defooted by final defooting). This point has been somewhat obscured by an overemphasis on Sievers's two-ictus view of the metre, but has emerged increasingly clearly in more recent research (cf. especially Cable (1991: 145f.; Fulk 1992: 203f.). Since Beowulf also conforms to Kaluza's law, its metrical system seems to represent a stage with shortened medial vowels and long final ones, precisely parallel to the stage suggested by Bermúdez-Otero.

26 The Merican NOM.-ACC.PL would develop along the same lines as the West Saxon forms in column II, only with $* \bar{e}$ as the umlaut product of $* \bar{e} a$, and no 'special feature' - accent or lexical marking - on the short $* \dot{l}$.
} 
${ }^{*}$ rìciu or *rīciju $(<*$ rikijo $),{ }^{27}$ which directly or indirectly developed into ricu with loss of $*_{-i}(j)-{ }^{28}$ Under the theory of high vowel loss adopted here, the singular is perfectly regular, as no deletion would be expected in *[rī][.cî]. The plural is less straightforward, since *[rī][.ci.(j)u] should also have formed two feet and been unaffected by high vowel deletion.

The traditional view holds that $r \bar{l} c u$ was produced directly from $* r \bar{l} c i(j) u$ by a process of high vowel deletion affecting vowels immediately after a heavy foot. The $* i$ takes the hit, so to speak, leaving the $* u$ to survive into the historical period. Attempts have been made to work this traditional historical explanation into a synchronic description of the inflection, but without the unstressed long vowels of early Old English it becomes difficult to explain why high vowel deletion should affect the $i$ in the plural / ri ciu/ but not in the singular/ríci/ (Dresher [1978] 1985: 173-91; Idsardi 1994: 228f.). To get around this issue, Fikkert et al., (2006: 135) proposed that the segment that surfaces as $-e$ is underlyingly actually a glide, $/ \mathrm{j} /$, as it was in Proto-Germanic: / $\overline{r i c j} /$ vocalizes to rice. The plural, however, is harder to account for under this view, and Fikkert, (2006: 135) have to add an ad hoc stipulation that if the high vowel was preceded by a glide [high vowel deletion] was also blocked; in that case the glide was deleted'.

Both of these synchronic theories attempt to take traditional views on high vowel deletion developed in a diachronic perspective and use them synchronically. A more effective synchronic description has been developed primarily without reference to historical categories: the best suggestion is that this class became part of a new synchronic category of $e$-stems (Keyser \& O’Neil 1985: 39-42, 44-45; Hogg \& Fulk 2011: ch. 3 passim, esp. 6972) ${ }^{29}$ The $e$ of /rîce/ surfaced without change in the singular, and served to protect the final $-u$ of the plural /rīceu/ from any synchronic morphophonological versions of high vowel loss. This -e- was lost not through any deletion of high vowels, but prevocalically as a simplification of the unstressed hiatus sequence /eu/.

This last attempt to explain the inflection synchronically suggests an alternative diachronic development to the classical theory as laid out by Campbell. If synchronically / rīceu/ becomes $r \bar{c} c u$ not through any high vowel deletion, but through the loss of the first vowel in unstressed hiatus, the simplest solution may be that this happened diachronically as well (Fulk 2010: 139f.). An earlier *rīciu would give *rīcu with no developments beyond those already postulated for a coherent synchronic description of later Old English. (12) shows how high vowel loss and simplification of a hiatus sequence interact to give the attested inflection of this class (as in 11, HVD stands for high vowel deletion, and HIATUs indicates the simplification of the unstressed hiatus sequence $\left.{ }^{*}-i u-\right){ }^{30}$

\begin{tabular}{|c|c|c|c|}
\hline & NOM.-ACC.SG & DAT.SG & NOM.-ACC.PL \\
\hline$P G m c$ & $*$ rì.ki.ja ${ }^{n}$ & *r1̄.ki.jai & *rī.ki.jō \\
\hline Pre-OE & $*[\mathrm{r} \overline{1}] .[\mathrm{c} \overline{1}]$ & $*[\mathrm{r} \overline{1}] . \operatorname{ci}[. \bar{\alpha}]$ & $*[\mathrm{r} 1][$.ci.u] \\
\hline$H V D$ & *r1.c1 & *rī.c $\overline{\boldsymbol{x}}$ & *rī.ci.u \\
\hline
\end{tabular}

27 The evidence that at a very early stage the form was $* r \bar{c} i j u$, with the glide was a real segment, is indirect, but good as far as it goes. The * ${ }_{-\imath}$ lying behind NOM.SG forms like ricce is traditionally explained as a coalescence of $*_{-i j}$ after the loss of final $*_{-} a$. The extension of some forms of class II weak verbs from *-o- to *-ōja- in Ingvaeonic also depends on a real glide in the class I weak verbs; see Cowgill (1959) for a full discussion. Precisely how the *-ijsequence developed after these early West Germanic and Ingvaeonic changes is less clear; see especially note 31 below.

${ }^{28}$ There are a few, very scattered instances of early Mercian and West Saxon of plural forms identical to the singular. Dahl (1938: 113) regards them, in my opinion correctly, as probably being mere scribal errors (note in particular that londgemēere 'boundaries' was corrected in the manuscript to -o at Orosius 14.27).

${ }^{29}$ See these references for a full account of the synchronic view of Old English noun classes entailed by this perspective. There does not seem to have been any dialectal variation in how these $e$-stems were formed, underlyingly or on the surface.

${ }^{30}$ The forms on this table are surface forms only. If Keyser \& O'Neil (1985) are correct, then the synchronic derivation would continue to mirror the historical development for a long time after the period discussed here. 


$\begin{array}{llll}\text { Hiatus } & * \bar{r} \cdot . \overline{1} & * \bar{r} . c \bar{Q} & * \bar{r} . c u \\ O E & \text { rīce } & \text { rīce } & \text { rīcu }\end{array}$

Any account of this noun class must allow for the loss of the medial glide somewhere between the Proto-Germanic *rikijo and the attested rīcu (see note 27 above). I assume that it was lost intervocalically at a relatively early date in the separate history of Old English. ${ }^{31}$

Although plurals like $r \bar{l} c u$ are readily explained by the traditional view of high vowel deletion as syncope, their development by no means depends on that theory. They are explainable as regular developments from *riciu, with the only loss coming from the simplification of a hiatus sequence. In his discussion of high vowel loss, Campbell (1983: 146) lists three forms as representative of the major categories that developed regularly: héafdu, ricu, and strengbu (see below on the last). Of these, the ricu-type is by far the most common and least variable, and since this class can be readily explained otherwise, the traditional theory loses much of its explanatory appeal.

\subsection{West Saxon Verbal Syncope}

In contrast to the handbooks, the starting point for Ringe's (2002) theory of double loss is the extra syncope found in West Saxon verbs such as wyrd 'becomes' and scinp 'shines', a category that has not otherwise traditionally received much attention as an example of high vowel deletion. These West Saxon verbs regularly contrast with those in other dialects, where the endings contain a vowel, for example, Anglian weorpeð, scineð. Ringe explains this divergence as the result of different analogical responses to a general Old English double reduction. He proposes an initial change of syncope (as he reconstructs it, *scinipi $>*_{s c i n p i}$ ) followed by apocope $\left({ }^{*} \operatorname{scin} p i>\sin p\right)$, ultimately eliminating both syllables. Since only apocope and not syncope affected light-stemmed verbs, such as *biripi 'carries' $>$ *birip, the verbal system ended up with a double set of verbal inflections which could be generalized variously. Either the light stem form *-ip, with its retained vowel, could be spread back to the

31 A different perspective is found in Ringe \& Taylor (2014: 290). Ringe points to forms of the verb gierwan 'to preprare', preterite gierede (along with a few similar verbs) to establish a relative chronology. This was originally a heavy class I weak verb, with pre-OE forms * garwijan, * garwid̄̄e. Ringe argues that there must have been an early, special reduction of $*_{-i j-}>*_{-j-}$, preceding the loss of $* w$ before $* i$, in order to give the contrast * gierwjan, with * $w$, and $*$ gierid $\bar{e}$, without. This, in turn, must have happened before high vowel syncope, in order to explain the preserved medial vowel of gierede. If these forms of this verb are all phonological, then this chronology is the correct one to infer. If accepted, this would mean, without question, that $r \bar{c} c u$ is an analogical form, as argued by Ringe (2002: 151). West Germanic * rikiju would have become ${ }^{*} r \bar{c} j u$ or ${ }^{*} r \bar{c} c u$ (depending on when the ${ }^{*} j$ was lost relative to high vowel

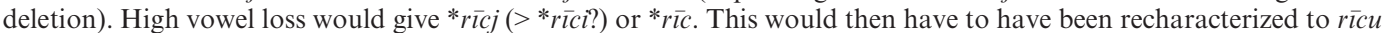
with surprising consistency across all dialects, becoming well-established by the time of even the oldest texts. Ringe is the only scholar I know of to make a serious case for $r \bar{c} c u$ being analogical, but his arguments on this matter are independent of any particular theory of high vowel deletion: under all theories *rīcju or *ricu would become *ric . However, the evidence of gierwan is not decisive, and it is entirely possible that the loss of *w before *i occurred after high vowel loss. If *-ij- had already developed into plain *-i-, as I argue, then an early infinitive *gierwian would have become gierwan by high vowel deletion, bleeding ${ }^{*} w$-loss. In the preterite, ${ }^{*}$ gierwid̄ $\bar{x}$ should presumably have become * gierudēe, by high vowel loss followed by syllabification of the semivowel. Such a highly anomalous form would have been very prone to restructuring, and in fact we find a wide variety of forms of the preterite. Alongside gierede and gigeruuid, both with the medial vowel regularized on the model of light class I weak verbs (and the latter with further restoration of the glide from the infinitive), we also find the verb as a class II weak verb in the Mercian of the Rushworth Gospels, a transition perhaps initially aided by the presence of $*-u$ - in the preterite. The regular 3sG.PRES giereð ought to be from *gierip $<*$ gierwip either way, its $*_{-} i$ - not being susceptible to high vowel loss under any relative chronology. Other potential evidence from $s \overline{\mathscr{e}}$ 'sea', $h r \bar{x}$ 'corpse', and $\bar{x}$ 'law' is not helpful in establishing the relative chronology, since final ${ }^{*}-w$ may have been lost word-finally after late $* \bar{e}$ just as it was after $* \bar{a}$ (cp. $h r \bar{a}, \bar{a}, s n \bar{a}$ 'snow', etc.). The correct relative chronology depends, in the end, on a fundamentally morphological judgement: is it more plausible for $r \bar{c} u$ or gierede to be the result of analogy? Given that the former is very widespread, and virtually exceptionless across words and dialects, while the latter coexists alongside a number of variants and was clearly morphologically unstable (for good phonological reasons), I prefer to take the neuter $j a$-stems as reflecting the more regular development. 
heavy stems (the Anglian development), or the reduced *- $p$ of the heavy stems could be generalized (the West Saxon choice).

Ringe's proposal is an innovative and thought-provoking attempt to explain this problem, but it creates a large number of problems concerning the prehistoric development of these verbal endings. Ringe also overstates both the implausibility of other ways of explaining the West Saxon peculiarities, and the possibility of analogical restoration of syncopated forms in Anglian.

Ringe's explanation requires that the 2 nd and 3 rd person singular verbal endings still be disyllabic in prehistoric Old English: *-isi and *-ipi from PIE *-ési, *-éti. Just when the final $*_{-} i$ of the verbal inflections was lost is not entirely clear, but it is more usually assumed that the final syllable was lost long before Old English began its separate development. Fulk (2010: 128f.) argues for a particularly early reduction, suggesting that final $*_{-} i$ was lost during the development of pre-Germanic as part of the same process that eliminated other, non-high vowels before Proto-Germanic (Ringe 2006: 116-18). Ringe is probably correct in following the traditional view that these endings did survive into Germanic, since in Gothic, forms like wairpis 'you go' point to a Proto-Germanic final syllable, *werpizi, protecting the word from being reduced to ${ }^{\times}$wairps (Ringe 2002: 142f; Brugmann 1886: 514). This final $*_{-i}$ is, however, usually supposed to have been lost in most Germanic dialects at a very early date, as suggested by the Vetteland inscription's ist 'is' < PIE * $H_{1}$ ésti (dated c. 350 according to Krause 1971: 172f.; Antonsen 1975: 38). Antonsen (1975: 16) suggests a sound change that deleted final $*_{-i} i$ when following an unstressed syllable, which would affect all

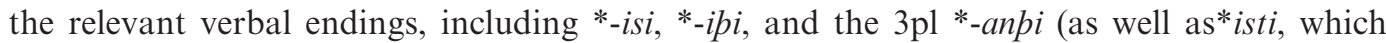
was syntactically unstressed). The North Germanic Runic evidence is only relevant to West Germanic as a parallel (Ringe 2002: 141, n. 8), but it is not unlikely that something similar happened in West Germanic. That it did is suggested by the doublet of Old English ond 'and' alongside Old High German enti, the former reflecting the unstressed, apocopated variant $*$ and, the latter retaining $*_{-i}$ when stressed (Ringe, personal communication). In order to keep the final syllable of *-isi and *-ipi, Ringe (2002: 143-146) has to propose a restriction on this loss of final $*_{-} i$, limiting it to after unstressed heavy syllables. This allows him to account for Runic ist, the lack of umlaut in the Old English 3rd plural ending $-a p<$ PGmc *-anpi, and the contrast of ond and enti, while also preserving *-ipi and $*_{-i s i}$ unchanged into the separate history of Old English. This is a more complicated conditioning than Antonsen's account, and also requires apocope of $*_{-} i s i, *_{-i p i}>*_{-} i s$, *$i p$ to be a separate change in every Germanic language individually; this more elaborate version of Germanic $i$-loss would only be justified by very strong evidence that *scinipi, etc., are required in early Old English.

It is far from clear that the shortened West Saxon verbs provide this sort of compelling evidence. Hogg \& Fulk (2011: 219-221) have recently defended the traditional view that syncopated forms arose before cliticized pronouns: e.g. ${ }^{*} \operatorname{sc} \overline{i n} i s p \bar{u}>{ }^{*} \operatorname{sc} \overline{i n} i . s t \bar{u}>{ }^{*} \operatorname{sc} \bar{\imath} s t \bar{u}$, with the $*_{-}-i$ - ending up in an open syllable when the $*_{\mathrm{s}}$ was resyllabified with the closely associated following element. Ringe (2002: 126-129) and Ringe \& Taylor (2014: 354f, n. 37) reject this proposal, chiefly on the grounds that cliticized forms would not have been frequent enough to form the basis for such widespread generalization. Our sources for very early West Saxon syntax are not rich, which makes it hard to know how plausible or implausible the clitic theory really is, but it is worth noting that in general, early Germanic syntax seems to have allowed a fair amount of pronoun cliticization with significant phonological effects (see the forms collected by Suzuki (1988: 218f.)). Furthermore, when we do find syncopated verb forms in Anglian they do tend to be accompanied by clitic pronouns, an association which may support the clitic theory (Hogg and Fulk 2011: 220f.). Cliticization also need not necessarily be the only factor at work promoting the spread and systematization of West Saxon verbal syncope, with 
reduction of allegro forms, loss of devoiced unstressed vowels (Ringe and Taylor 2014: 277f.), and overgeneralization of the morphophonological deletion of high vowels all potentially playing a role. If some form of the traditional explanation is sufficient to account for West Saxon syncope, then the necessity of Ringe's alternative is less obvious.

Another significant consideration telling against Ringe's proposal is that the actual distribution of verb forms is the wrong way around from what we would expect if West Saxon $\operatorname{scin} p$ were phonologically regular and Anglian scineð analogical. The oldest texts, all Anglian and probably from the late 7th or early 8th centuries (Pheifer 1974: 1xxxixf. (section 88); Fulk 1992: 390f.), uniformly show unsyncopated forms. ${ }^{32}$ Ringe (2014: 292) dates apocope roughly to the early 7 th century, giving barely a century for the restored scined type to have become thoroughly generalized in Anglian, becoming standard even in the conservative language of poetry. This is all the more surprising since the analogical basis for restoring the endings is not strong. This theory requires the numerous long-stemmed verbs to fill out their endings solely on the basis of their short-stemmed counterparts, although in other ways the language tolerated a continuing lack of parallelism between short and long verbs. The West Saxon verbs show more variation in syncope, and while this may be in part due to Anglian literary influence introducing restored forms, this would only reinforce how quickly and thoroughly the unsyncopated forms became standard in Anglian. The overall picture more naturally suggests that the older, more consistent, and more widespread situation - the unreduced scineð type - represents the general Old English development, while the West Saxon scin $p$ forms are a later innovation peculiar to that dialect.

This view is reinforced by the lack of other words that show this double loss. One of Ringe's two categories of supporting evidence, ipu-stems like streng $p(u)$, will be dealt with below - if anything, they speak strongly against the fully reduced forms being phonologically regular. The other category is an isolated set of three jo-stems, bliss 'joy, merriment', liss 'kindness, favour', and milts 'kindness, mercy', which are all clearly derived from the adjectives bliðe 'joyful', liðe 'soft, kind, gentle', and milde 'gentle, mild'. The stem class of these words in English is not immediately apparent, but the Old Saxon cognate of bliss is blìdsea, a jo-stem. It has traditionally been assumed that the earlier forms are *blipisi $(<\mathrm{PGmc} *$ blipis $\vec{\imath})$, etc., as proposed by Luick (1921: 286) and Kluge (1926: 77), and followed by Sievers \& Brunner (1965: 210), Ringe (2002: 138), and Ringe \& Taylor (2014: 14, 291). The assumption seems to be the same as in Wright (1910: 72, 150), that the 'heavy' Sievers's alternants, in this case feminine $*_{-} \bar{l}^{33}$ should occur in polysyllables of any shape. Under a more current understanding of Sievers' law, however, this reconstructed form can hardly be correct, since after an unresolved light syllable the NOM.SG ending should be the light alternant, PGmc *-jo rather than $*_{-} \bar{l}$ (cf. Kiparsky 1998: 353). This is not only theoretically expected, but supported by a large number of nouns, including those formed with the well-attested suffixes -

32 As mentioned above, the few syncopated long-stemmed verbs are usually associated with following pronouns. The only regularly syncopated Anglian verb is the short-stemmed cwið 'says' ( $<*$ cwiðið), which is most likely simply haplology in a very frequent word.

33 It seems clear that the 'heavy' Sievers's alternant of the $j \bar{o}$-stems was rather irregularly $*_{-} \bar{l}$, shortened in Northwest Germanic to *-i, rather than the more predictable *-ijo, so that Old English bend 'bond' is from *bendi< ${ }^{*}$ band $\bar{\imath}$ (Ringe and Taylor 2014: 14). The ${ }^{*}-\bar{\imath}$ is still overtly reflected in Gothic bandi (Sievers 1878: 87f, 96). Ringe (2014: 135) suggests that since the $j \bar{o}$-stem $m \bar{\imath}$ ' 'mile' was borrowed from Latin NOM.-ACC.PL milia, it might imply that the Germanic NOM.SG ending had been remodelled to the morphologically more regular *-iju in West Germanic (as reconstructed by Wright and Wright 1925: 383f.), with this form being needed in order to provide a point of overlap between the Latin and Germanic inflections. This would then provide further evidence for his double loss of the entire sequence *-iju. This does not seem likely, however, since if the Latin desinence -ia was equated with Germanic *-iju, why was the Latin neuter plural not borrowed as a neuter plural $a$-stem, just as close formally and more precise grammatically? It seems more probable that the Latin ending was equated with the more exactly matching West Germanic $j \bar{o}$-stem plural forms, NOM. *mïlijo, ACC. *milijā, from which the singular *mïl was straightforwardly formed. 
$n i s(s)$, -en $(n)$, and -es $(s) .{ }^{34}$ Since *blïpisjo can hardly develop into bliss - the expected outcome would be ${ }^{\times} \operatorname{bl} \succsim e s(s)$ - it is probably better to reconstruct this small word family as a late, Ingvaeonic development that simply never had a connecting vowel: *blipsi, etc. (Fulk 2010: 129; compare Krahe \& Meid 1967: 161).

If words like streng $p$ do not support double loss, and early Old English *blipisi is unlikely to have ever existed, then West Saxon verbal syncope appears even more isolated, in terms of both dialect and category. Without any corroborating evidence, and in the face in the numerous and often problematic analogies required by this hypothesized double loss, it is preferable to retain the traditional view of Old English verbs, with Anglian scined directly reflecting early Old English *scinip. However the further syncope of West Saxon $\operatorname{scin} p$, etc., is to be explained, it should be seen as a problem of innovation in that one variety of Old English, not an issue for the language as a whole.

\subsection{Streng $p(u)$, etc}

The class of feminine abstract nouns represented by streng $p(u)$ is cited by both Ringe (2002) and Campbell (1983) in support of their respective theories of high vowel loss. A number of the basic facts are fairly clear. The original shape of the suffix in question was clearly pre-OE *-ipu < PGmc *-ipō (compare OE hêhpo and Gothic hauhipa, both 'height'), but the medial $*_{-} i$ - is always syncopated in attested Old English. As the parentheses indicate, the NOM.SG in this class is attested both with and without a final $-u /-o$, and the first question that arises is which, if either, of these forms is phonologically regular, and how any non-phonological forms would have arisen.

Neither streng $p u$ nor streng $p$ is, of course, the expected phonological development under the view of high vowel loss proposed here. A preform like *strengipu should have been retained as such without loss of either vowel. This is, however, not a significant problem, and does not give any real support to the other views of high vowel loss. Outside of the nominative, all the endings were long, meaning that in most of the paradigm the medial $*_{-} i$ - would have been left unfooted and deleted. It would be a very straightforward morphological change to extend the syncopated stem into the anomalous nominative as well (Fulk 2010: 140f.). Light stemmed members of the class also lost their medial $*_{-i-}$, e.g. trymp 'strength, support' $<*^{*}$ trymipu, which, under any theory, must have happened by analogy with the heavy stems.

This analogical process would suggest that strengpu is the older of the two attested forms, which is what is traditionally assumed. Ringe (2002: 139) dissents, arguing that the forms without $-u$, in which both high vowels have been lost, are regular. He suggests that the $-u$ was restored sporadically through a chain of analogies. First, in the distinct class of $\overline{i n}$-stems (also mostly abstract nouns), an inherited invariant final $*_{-} e<*_{-} \bar{\imath}$ was replaced in the NOM.SG by $-u$, on the strength of the $-u \sim-e$ paradigmatic alternation found in light $\bar{o}$-stems like giefu 'gift', oblique giefe (Ringe 2002: 149). This pattern would then have been extended to the semantically associated $p$-abstracts.

Both of these analogical processes proposed by Ringe (2002) are highly improbable. Concerning the $\bar{m}$-stems, in early Old English they would have had no close parallelism with the $\bar{o}$-stems: the former class ended in an invariant $*-\bar{l}$, while the oblique endings of the latter contained only non-high vowels. Only during the historical period did these quite separate vowels merge into the $-e$ familiar from later texts. Even if the $\overline{i n}$-stems should somehow have

\footnotetext{
34 Another example is hagtes ( $s$ ) 'witch', cited by Fulk (2010: 129). Ringe (2014: 293, n. 38) objects that this word has been reformed, and that in any case $h \bar{a} t s$, i.e. *hagts, is attested, as his theory predicts. However, if *hagts were the regular form of this word, it is hard to understand what the motivation for further remodelling would have been. On the other hand, Ringe has collected a number of examples of vowel loss before $s$, a process which plausibly accounts for the (rare) form hēts (277f.) Unreduced haegtis is found in the early glossaries (Épinal 913, Corpus 1913).
} 
acquired a $-u$ ending, the extension of this to the $i p u$-stems would have had to be on a purely semantic basis, since by Ringe's hypothesis the latter class should have already fallen together with the $\bar{o}$-stems, $j \bar{o}$-stems, and feminine heavy $i$-stems to become a formally indistinguishable part of the general strong feminine declension. Despite this, historically light ibu-stems such as trymp 'strength' never receive this 'analogical' $-u$, despite being formally and semantically indistinguishable from their historically heavy counterparts, such as streng $p$, under Ringe's hypothesis. $^{35}$

Even granting these early analogies, there is still a further problem with assuming that the $-u$ in streng $p u$ is analogical. In contrast to other feminine nouns, in the ibu-abstracts the $-u$ is frequently extended beyond the NOM.SG. It is found in the accusative even in early West Saxon, and can be found in all the oblique cases in the Mercian of the Vespasian Psalter (Dahl 1938: 1436; Hogg \& Fulk 2011: 28f. and 120f.). If the interchange of $-u$ and $-e$ was such a robust morphological pattern that it could bring NOM.SG $-u$ into the $\overline{i n}$ - and ipu-stems, what is the motivation for extending the same $-u$ beyond the nominative (in this class only), disrupting precisely the alternation that was supposed to have allowed the restoration of $-u$ in the first place?

On the other hand, this extension is well-motivated under the assumption that strengpu is more conservative than streng $p$. This was the only category of feminines with a final $-u$ after a heavy stem, a salient feature that was spread as a distinctive part of the class's inflection. This tendency was carried furthest in Mercian, while in West Saxon it competed with the pressure to analogically get rid of the $-u$ and bring the class in line with the standard strong feminine inflection.

\subsection{Phonology and morphology}

As any survey of the forms involved makes clear, Old English as attested does not perfectly reflect the phonological operation of high vowel loss, however formulated. In the empirical comparison of the various theories, the key questions are, firstly, whether the proposed phonology explains any of the data more usefully than other approaches; and secondly, how plausibly the remaining forms can be accounted for morphologically. Naturally the simple cases, such as the difference between word and scipu, are easily explained by any theory, and are of little use in deciding between various explanations.

Ringe's proposed double loss is phonologically advantageous only in explaining syncopated West Saxon verbs. Other forms held to show this double loss either should be reconstructed with different early Old English forms (so bliss, which cannot be from *blipisi), or have more morphological variation than they ought if they were phonologically regular (so streng $p$ alongside streng $p u$ ). Against this, it requires a great deal of analogy in feminine nominative singulars, neuter nominative-accusative plurals of various sorts, and Anglian verbal endings. Although some of these changes are plausible individually, it is unlikely that all of these analogies happened in precisely the way this theory requires, and their extreme uniformity of operation throughout even the oldest Old English is a major problem.

The traditional view, in which only the first of two high vowels are deleted in words like héafudu, requires considerably less analogy. However, it also does much less phonological work. The main distinctive categories it explains well are neuter nominative-accusative plural $j a$-stems like $r \overline{i c} u$ and $i p u$-stems like streng $p u$. Since the vowel losses in each of these categories are easily explained in other ways - respectively, vowel deletion in hiatus, and simple levelling of the stem from oblique case forms - this form of high vowel deletion cannot claim any great explanatory power.

\footnotetext{
${ }^{35}$ This change would have also had to be early enough to enter the conservative language of verse by the time

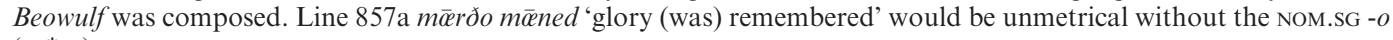
$(<*-u)$.
} 
Furthermore, neither of these theories can account for forms like hêfudu or lytelu, which involve the unmotivated restoration of lost vowels, and they are particularly hard put to explain the paradigmatic variation of these forms with heafde, lytle, etc. It is precisely these difficult forms and alternations that are explained as regular phonological developments by the current theory of high vowel loss. The analogies involved in other forms are constrained, only applying in a few well-motivated contexts where morphological change is usually needed anyway to account for variants. The shortening of unstressed vowels provided the primary motivation for change by obscuring the conditioning of the old system, with the change of *hēafd $\bar{e}>* h \bar{e} a f d a$ leading to the various attested restructurings of *héafudu (for details, see see Bermúdez-Otero 2005b: 24-34; Fulk 2010: 137-9). Also very well motivated is the change of *strengipu $\rightarrow$ *streng $p u$, under the pressure of syncope throughout the oblique. The further changes that affected this class are also very straightforward, with some degree of analogy, at any rate, demanded by the coexistence of streng $p$ and streng $p u$, and the spread of $-u$ beyond the NOM.SG. All other analogies, such as the restoration of the 1st singular verbal ending in Anglian verbs like sing $u$ 'I sing', have to be assumed by any phonological theory of high vowel loss, and are in any case generally very straightforward. ${ }^{36}$

\section{CONCLUSION}

In this paper I have tried to present a view of early Old English foot structure that is a theoretical improvement on previous formulations, is congruent with the metrical evidence of Kaluza's law, and which provides a good starting point for the phonological and morphological changes to unstressed high vowels. The principles themselves are very straightforward, and I repeat them from section 5, adding in the additional corollary proposed on the basis of metrical evidence of Kaluza's law in section 6.2:

(13) Feet are formed from left to right, grouping syllables into bimoraic units.

a. The first syllable must be footed, even if this creates an overheavy foot of more than two moras.

b. Otherwise feet are strictly bimoraic.

c. Non-initial syllables that cannot be accommodated within this process are left unfooted.

d. If the head of the second element of a compound would be left unfooted by the above rules, it instead forms a degenerate, monomoraic foot.

${ }^{36}$ Hogg (2000: 363) suggests that this ending may never have been lost, with high vowel deletion having always been partly morphologized (also compare Suzuki 1988). As evidence of this, he points to the regularity of this ending in the Vespasian Psalter, though this is not among the very earliest Old English texts. There are actually no examples of a restored ending from the very oldest Old English texts: fullēstu at Beo 2668b, gifyrdro and arectio at Erfurt 327 and $396 \mathrm{a}$, and groetu and mengio at Épinal 210,659 are all heavy-stemmed class I weak verbs (with, perhaps, the exception of the last, which may be class II, where retention of the *- $u$ is equally expected). In the slightly later Corpus Glossary there are clearer signs of analogy, and I find seven instances of restored $-u / o(514,661,1137,1138,1240,1881,1959$; it also has some ten entries where the ending is historical: $139,440,526,678,688,1285,1568,1673,1828,1887,2137)$. It is not difficult to understand why this restoration would have happened soon after the phonological basis for high vowel deletion began to become opaque, since verbs like *sing 'I sing' would have been under pressure from both shortstemmed strong verbs (*gefu 'I give') and long-stemmed weak verbs ( ${ }^{*}$ dømu 'I judge' <*domiu) to restore the ending.

\begin{tabular}{|c|c|c|c|}
\hline & STRONG & & Weak I \\
\hline SHORT & $*_{\downarrow}$ gefu & $\rightarrow$ & $\underset{\uparrow}{* \text { swebb }}$ \\
\hline LONG & $* \operatorname{sing}$ & $\leftarrow$ & *dœmu \\
\hline
\end{tabular}

Syncope of the old ending also helps explain why Kentish and West Saxon were in a position to import the subjunctive ending - $e$ to mark this category. Different analogical pressures in the different dialects may explain the adoption of different solutions, restoration versus importation; see Cowgill ([1965] 2006: 428-31 (45-9)). 
(14) If a syllable has not otherwise been footed, a final consonant may optionally count as extrametrical, if necessary to allow the creation of a bimoraic final foot.

(15) Unless followed by an extrametrical consonant, final feet are destressed.

The rule for high vowel loss is also very simple, once this foot structure is in place:

(16) Unfooted high vowels are deleted.

This system as described here strictly applies only to 'early Old English', a largely prehistoric phase possibly directly reflected only in Beowulf. The oldest prose texts, such as the early glossaries, show only minimal restructurings, as is to be expected. Later texts show a much wider range of developments, varying significantly by dialect.

It is beyond the scope of this paper to explore either the full range of these later developments, or the earlier background of Germanic prosody, but it seems likely that the basic principle of bimoraism played a significant and enduring role in Germanic and English metrical phonology. The Germanic preference for bimoraic units has been recognized and discussed, both in the context of 'Prokosch's law' (a term coined by Riad 1992: 45-7, cf. Murray \& Vennemann 1983: 514, 525) and elsewhere (e.g. Kiparsky 1998; Bermúdez-Otero 2005b: 33). Looking later, Bermúdez-Otero (2005b) has provided a good model for the subsequent stages of Old English which fits neatly with the theory of early Old English feet proposed here. ${ }^{37}$ Bimoraic feet continued to play a role in these later stages, and even, in some form, in early Middle English phonology and metrics (Tolkien 1929: 117ff; Fulk 2002). The early Old English system has a distinctive place in this larger line of development, standing out both for its close connection to the workings of resolution in Beowulf, and as the context in which the morphologically significant process of high vowel loss arose and operated with the most regularity.

\section{Nelson Goering,}

Wolfson College

Linton Road

Oxford, $O X 26 U D$.

United Kingdom

Email: nelson.goering@ling-phil.ox.ac.uk

\section{REFERENCES}

Antonsen , Elmer H. 1975. A concise grammar of the older Runic inscriptions. Tübingen: Max Niemeyer.

Bermúdez-Otero, Ricardo. 2005a. Appendix B: Neuter a-stem nouns in Rushworth2. Ms. www.bermudezotero.com/lifecycle_appendixB.pdf, (accessed 5 Nov 2015).

Bermúdez-Otero, Ricardo. 2005b. A-stem nouns in West Saxon: Synchrony. Ms. http://www.bermudez-otero.com/ lifecycle_chapter4.pdf, (accessed 5 Nov 2015).

Bermúdez-Otero, Ricardo \& Richard M. Hogg. 2003. The actuation problem in optimality theory: Phonologization, rule inversion, and rule loss. In D. Eric Holt (ed.) Optimality theory and language change. Dordrecht: Springer Science+Business Media. 91-120.

Bliss, Alan J. 1962. The metre of Beowulf. Oxford: Blackwell.

BoutKan, Dirk. 1995. The Germanic Auslautgesetze. Amsterdam: Rodopi.

Braune, Wilhelm. 2004. Althochdeutsche Grammatik I: Laut- und Formenlehre. 15th edn. Edited by Ingo Reiffenstein. Tübingen: Max Niemeyer Verlag.

37 Bermuúdez-Otero's most archaic phonological system, 'state A' in his terminology, could have developed immediately out of the foot structure described here after the shortening of unstressed long vowels. 
Brugmann, Karl. 1886. Grundriss der vergleichenden Grammatik der indogermanischen Sprachen. Volume 1. Einleitung und Lautlehre. Strassburg: Karl J. Trübner.

Cable, Thomas M. 1974. The meter and melody of Beowulf. Urbana, IL: University of Illinois Press.

Cable, Thomas M. 1991. The English alliterative tradition. Philadelphia, PA: University of Pennsylvania Press.

Cable, Thomas M. 1994. Syllable weight in Old English meter: Grids, morae, and Kaluza's law. Diachronica 11(1). 111.

Cameron, Angus, Ashley Crandell Amos, Antonette diPaolo Healey, et al., (eds). 2007. Dictionary of Old English: A to G Online. Toronto Dictionary of Old English Project. http://tapor.library.utoronto.ca/doe/. (accessed 5 Nov 2015).

Campbell, Alistair. 1983. Old English grammar. Corrected reprint. Oxford: Oxford University Press.

Cowgill, Warren. 1959. The inflection of the Germanic ō-presents. Language 35(1). 1-15.

Cowgill, Warren. (1965) 2006. The Old English present indicative ending -e. In Jared S. Klein (ed.), The Collected Writings of Warren Cowgill. Ann Arbor, N.Y.: Beech Stave Press. 427-31.

Dahl, Ivar. 1938. Substantival infexion in Early Old English: Vocalic stems. Lund: C.W.K. Gleerup.

Dresher, B. Elan. [1978] 1985. Old English and the theory of phonology. PhD diss., University of Massachussetts.

Dresher, B. Elan \& Aditi Lahiri. 1991. The Germanic foot: Metrical coherence in Old English. Linguistc Inquiry 22 (2). 251-286.

Fikkert, Paula, B. Elan Dresher\& Aditi Lahiri. 2006. Prosodic preferences: From Old English to Early Modern English. In Ans van Kemenade and Bettelou Los (eds.), The handbook of the history of English, Oxford: Blackwell. $125-150$

FulK, R. D. 1992. A history of Old English meter. Philadelphia, PA: University of Pennsylvania Press.

FulK, R. D. 1998. Secondary stress phenomena in the meter of Beowulf'. Interdisciplinary Journal of Germanic Linguistics and Semiotic Analysis 3. 279-304.

FulK, R. D. 2002. Early Middle English evidence for Old English meter: Resolution in Poema morale. Journal of Germanic Linguistics 14(4). 331-355.

FulK, R. D. 2007. Old English meter and oral tradition: Three issues bearing on poetic chronology. The Journal of English and Germanic Philology 106(3). 304-324.

Fulk, R. D. 2010. The roles of phonology and analogy in Old English high vowel deletion. Transactions of the Philological Society 108(2). 126-144.

Fulk, R. D., Robert E. Bjork \& John D. Niles, (eds). 2009. Klaeber's Beowulf and the Fight at Finnsburg. 4th edn. Corrected reprint. Toronto: University of Toronto Press.

Halle, Morris, Wayne O`Neil, and Jean-Roger. Vergnaud. 1993. Metrical coherence in Old English without the Germanic foot. Linguistic Inquiry 24(3). 529-539.

Hayes, Bruce. 1995. Metrical stress theory: Principles and case studies. London: The University of Chicago Press.

Hogg, Richard M. [1992] 2011. A grammar of Old English. Vol. 1: Phonology. Oxford: Wiley-Blackwell.

HogG, Richard M. 2000. On the (non-)existence of high vowel deletion. Berlin: Mouton de Gruyter. 353-376.

Hogg, Richard M. and R. D. Fulk. 2011. A grammar of Old English. Vol. 2: Morphology. Oxford: Wiley-Blackwell.

Hutcheson, B.R. 2004. Kaluza's law, the dating of Beowulf, and the Old English poetic tradition. The Journal of English and Germanic Philology 103(3). 297-322.

Hutton, John. 1998. The development of secondary stress in Old English. In Linda van Bergen \& Richard M. Hogg (eds.), Historical Linguistics 1995, edited by, vol. Volume 2: Germanic Linguistics. Amsterdam: John Benjamins. $115-30$.

Idsardi, William J. 1994. Open and closed feet in Old English. Linguistic Inquiry 25(3). 522-533.

JASANOFF, JAY. 2002. The nom. sg. of Germanic $n$-stems. In Alfred Wedel \& Hans-Jorg Busch (eds.), Verba et littera: explorations in Germanic languages and German literature. Newark DE: Linguatext. 31-46.

Kaluza, Max. 1896. Zur Betonungs- und Verslehre des Altenglischen. In Festschift zum siebzigsten Geburtstage Oskar Schade. 101-133.

Keyser, S. J. \& Wayne O’Neil. 1985. Rule generalization and optionality in language change. Studies in generative grammar 23. Dortrecht: Foris Publications.

KiPARSky, PAul. 1998. Sievers' law as prosodic optimization. In Lisi Oliver, Jay Jasanoff \& H. Craig Melchert (eds.), Mir Curad: Studies in honor of Calvert Watkins. Innsbruck: Innsbrucker Beitrage zur Sprachwissenschaft. 345-360.

Kiparsky, Paul, and Wayne O'Neil. 1976. The phonology of Old English inflections. Linguistic Inquiry 7(4). 527557.

Kluge, Friedrich. 1926. Nominale Stammbildungslehre der altgermanischen Dialekte. 3rd edn. Edited by Lugwig Sütterlin \& Ernst Ochs. Halle: Max Niemeyer.

Krahe, Hans \& Wolfgang Meid. 1967. Germanische Sprachwissenschaft III: Wortbildungslehre. Berlin: Walter de Gruyter.

Krause, Wolfgang. 1971. Die Sprache der urnordischen Runeninschriften. Heidelberg: Carl Winter.

KuHn, Hans. 1939. Westgermanisches in der altnordischen Verskunst. Beitrage zur Geschichte der deutschen Sprache und Literatur 63. 178-236.

Luick, Karl. 1921. Historische Grammatik der englischen Sprache. Leipzig: Chr. Herm. Tauchnitz.

Murray, Robert W. \& Theo Vennemann. 1983. Sound change and syllabic structure in Germanic phonology. Language 59(3). 514-528.

Neidorf, Leonard \& Rafael J. Pascual. 2014. The language of Beowulf and the conditioning of Kaluza's Law. Neophilologus 98. 657-73. 
Noreen, Adolf. [1923] 1970. Altnordische Grammatik I. Altislandische und altnorwegische Grammatik (Laut- und Flexionslehre), unter Berucksichtigung des Urnordischen. 4th edn. Tuscaloosa, AL: The University of Alabama Press.

Pheifer, J. D., (ed). 1974. Old English glosses in the Épinal-Erfurt glossary. Oxford: Oxford University Press.

Prokosch, Eduard. 1939. A comparative Germanic grammar. Philadelphia, PA: The Linguistic Society of America.

Riad, Tomas. 1992. Structures in Germanic prosody. PhD diss., Stockholm University.

Ringe, Don. 2002. Syncopated present indicative forms in Old English. In Alfred R. Wedel \& Hans-Jörg Busch (eds.), Verba et litterae: Explorations in Germanic languages and German literature - essays in honor of Albert L. Lloyd. Newark, DE: Linguatext. 125-56.

Ringe, Don. 2006. From Proto-Indo-European to Proto-Germanic. Vol. 1. A linguistic history of English. Oxford: Oxford University Press.

Ringe, Don \& Ann Taylor. 2014. From Proto-Germanic to Old English. Vol. 2. A linguistic history of English. Oxford: Oxford University Press.

Russom, Geoffrey. 1987. Old English meter and linguistics theory. Cambridge: Cambridge University Press.

Russom, Geoffrey. 1998. Beowulf and Old Germanic metre. Cambridge studies in Anglo-Saxon England 23. Cambridge: Cambridge University Press.

Russom, Geoffrey. 2001. Metrical evidence for subordinate stress in Old English. Journal of Germanic Linguistics 13 (1). 39-64.

Russom, Geoffrey. 2002. A bard's-eye View of the Germanic syllable. The Journal of English and Germanic Philology 101(3). 305-328.

Sievers, EduARD. 1878. Zur Accent- und Lautlehre der germanischen Sprachen. Halle: Max Niemeyer.

SieVERS, EdUARD. 1885. Zur Rhythmik des germanischen Alliterationverses I. Beiträge zur Geschichte der deutschen Sprache und Literatur 10. 209-314.

Sievers, Eduard. 1893. Altgermanische Metrik. Halle: Max Niemeyer.

Sievers, Eduard, and Karl Brunner. 1965. Altenglische Grammatik. 3rd edn. Tübingen: Max Niemeyer.

Stiles, Patrick. 1988. The Gothic nominative singular brōpar 'brother' and the reflexes of Indo-European long vowels in the final syllables of Germanic polysyllables. Transactions of the Philological Society 86(2). $115-143$.

Stockwell, Robert P. \& Donka Minkova. 1997. Old English metrics and the phonology of resolution. NOWELE 31 (2). 389-406.

Suzuki, SeIICHI. 1988. On the 1 sg. pres. ind. ending $-u$ and high vowel deletion in Anglian and other West Germanic languages. Indogermanische Forschungen 93. 210-224.

Suzuki, Seirchi. 1992. On reducing type D* to type D in the meter of Beowulf. Neuphilologische Mitteilungen 93. 25769.

Suzuki, Seirchi. 1996a. Preference conditions for resolution in the meter of Beowulf: Kaluza's law reconsidered. Modern Philology 93(3). 281-306.

Suzuki, SeIICHI. 1996b. The metrical organization of Beowulf: Prototype and isomorphism. Trends in linguistics: Studies and monographs 95. Berlin: Mouton de Gruyter.

Terasawa, Jun. 2011. Old English metre: An introduction. Toronto: University of Toronto Press.

Tolkien, J. R. R. 1929. Ancrene Wisse and Hali Meidhad. Essays and Studies 14. 104-216.

Tolkien, J. R. R. 1982. Finn and Hengest: The fragment and the episode. Edited by Alan Bliss. Boston, MA: Houghton Mifflin.

Weiskott, Eric. 2012. A semantic replacement for Kaluza's law in Beowulf. English Studies 93(8). 891-896.

Wright, Joseph. 1910. Grammar of the Gothic language. Oxford: Oxford University Press.

Wright, Joseph \& Elizabeth Mary Wright. 1925. Old English grammar. 3rd edn. Oxford: Oxford University Press.

Yakovlev, Nicolay. 2008. The development of alliterative metre from Old to Middle English. D.Phil. diss., University of Oxford. 